\title{
A cidadania brasileira à luz dos valores neoconstitucionais: Uma análise da democracia participativa no Brasil do século XXI
}

\author{
Brazilian citizenship in the light of neoconstitutional values: An analysis of participatory democracy in 21st
} century Brazil

La ciudadanía brasileña a la luz de los valores neoconstitucionales: Un análisis de la democracia participativa en el Brasil del siglo XXI

Gabriela Ornelas Marinho do Espirito Santo ORCID: https://orcid.org/0000-0003-1955-863X Universidade Salvador, Brasil E-mail: gabriela.direitoadv@hotmail.com

\begin{abstract}
Resumo
Este artigo busca analisar o processo de cidadania brasileira a luz dos valores neoconstitucionais, inserido em uma realidade informacional cuja importância das redes digitais para os movimentos, reuniões e deliberações sociais, produz o espaço público digital propício ao amplo debate e informação. O objetivo geral é desenvolver um estudo sobre a viabilidade de se implantar uma cultura constitucional no Brasil através do fomento de uma educação cidadã, tendo como base os princípios neoconstitucionais contido na Carta Magna de 1988, vislumbrando uma melhor gestão pública diante de uma melhor compreensão por parte da população das dinâmicas e princípios democráticos. Para o desenvolvimento do trabalho, foi utilizado a pesquisa bibliográfica com análise de livros, teses, dissertações e artigos que versam sobre o tema. Como resultado de pesquisa, verificou-se que, a cidadania brasileira, deficitária por nascimento, necessita ser ressignificada em valores humanos a partir da mais tenra idade, de modo a contribuir a médio e longo prazo com o desenvolvimento nacional de forma ampla e significativa, efetivando os preceitos da Constituição Brasileira de 1988.

Palavras-chave: Cidadania; Constituição de 1988; Democracia; Direitos humanos; Educação; Gestão pública; Globalização; Mídias sociais.

Abstract

This article seeks to analyse the process of Brazilian citizenship in the light of neoconstitutional values, inserted in an informational reality whose importance of digital networks for social movements, meetings and deliberations, produces a digital public space conducive to broad debate and information. The general objective is to develop a study on the feasibility of implementing a constitutional culture in Brazil through the promotion of citizen education, based on the neoconstitutional principles contained in the 1988 Magna Carta, envisioning a better public management in view of a better understanding by part of the population of democratic dynamics and principles. For the development of the work, bibliographical research was used with analysis of books, theses, dissertations and articles that deal with the theme. As a result of research, it was found that Brazilian citizenship, deficient by birth, needs to be re-signified in human values from an early age, in order to contribute in the medium and long term to national development in a broad and significant way, implementing the precepts of the Brazilian Constitution of 1988.
\end{abstract}

Keywords: Citizenship; 1988 Constitution; Democracy; Human rights; Education; Public management; Globalization; Social media.

\section{Resumen}

Este artículo busca analizar el proceso de ciudadanía brasileña a la luz de los valores neoconstitucionales, insertos en una realidad informativa cuya importancia de las redes digitales para los movimientos sociales, encuentros y deliberaciones, produce un espacio público digital propicio para un amplio debate e información. El objetivo general es desarrollar un estudio sobre la factibilidad de implementar una cultura constitucional en Brasil a través de la promoción de la educación ciudadana, con base en los principios neoconstitucionales contenidos en la Carta Magna de 1988, vislumbrando una mejor gestión pública en vista de una mejor comprensión por parte de de la población de dinámicas y principios democráticos. Para el desarrollo del trabajo se utilizó la investigación bibliográfica con análisis de libros, tesis, disertaciones y artículos que abordan el tema. Como resultado de la investigación, se encontró que la ciudadanía brasileña, deficiente por nacimiento, necesita ser resignificada en los valores humanos desde una edad temprana, a fin de contribuir en el mediano y largo plazo al desarrollo nacional de manera amplia y amplia. de manera significativa, implementando los preceptos de la Constitución brasileña de 1988. 
Palabras clave: Ciudadanía; Constitución de 1988; Democracia; Derechos humanos; Educación; Gestión pública; Globalización; Redes sociales.

\section{Introdução}

É cediço que a participação do brasileiro na efetivação de seus direitos fundamentais é de extrema deficiência, seja por conta da diminuta participação na tomada de decisões, seja pelo desconhecimento do funcionamento do Estado Democrático de Direito e dos seus institutos, seja pela fragilidade de uma cultura constitucional.

Bem verdade que, o que há é um foço cada vez mais profundo, entre os interesses públicos fundamentais previstos na Constituição Federal de 1988 e sua devida e necessária efetivação pelos atores jurídicos-políticos.

Esses entraves à implementação de políticas públicas para concretizar a Constituição Federal de 1988, têm suas raízes em um histórico nacional de exclusão, dominação e objetificação dos sujeitos, que juntos resultaram na artificialidade das leis e consequente insatisfação com os três poderes no combate aos desafios do país.

A Constituição de 1988 prevê como um direito social fundamental o direito à educação, por entender, o constituinte, que é através da educação universal, livre, plural, gratuita, democrática e de qualidade, que é possível o pleno desenvolvimento da pessoa, seu preparo para o exercício da cidadania e sua qualificação para o trabalho. Entretanto, apesar do mandamento Constitucional de caráter programático, tal direito encontra barreira na escassez de recursos financeiros e na escolha de prioridades dos entes federativos.

Outrossim, no artigo 205 da CRFB/88 consta, de modo expresso, que o direito a educação é um dever não só da família, mas também, do Estado.

Destarte, a educação é o ponto inicial para integrar a sociedade e organizá-la em torno de espaços públicos (virtuais ou não), para que possam compreender, debater, deliberar e propor mudanças na esfera pública, diminuindo a distância entre os órgãos de decisão e o povo, permitindo que este passe a se interessar diretamente pelos assuntos sociais, como se individuais fossem, e passem a comprometerem-se com o desenvolvimento social e a corroborar com as políticas públicas para concretizar os anseios do constituinte de 1988.

É através do ensinamento e aprendizagem que se há adesão aos direitos humanos e ao constitucionalismo, sendo somente por meio da educação em valores e princípios que informam as liberdades e as normas constitucionais que é possível alcançar uma educação para uma vida em comunidade, para a cidadania.

Busca-se compreender o alcance e importância dos direitos, garantias e deveres fundamentais, dialogando com o Direito constitucional a educação cidadã, cuja cultura neoconstitucional resulte em desenvolvimento social, bem como tecendo as críticas necessárias ao papel dos atores jurídico-políticos em face dos deveres fundamentais e na concretização da Constituição de 1988, diante da frágil cultura constitucional.

O objetivo central do Estado é formar indivíduos que pensem e ajam respaldados em valores humanos para que em todo o País, seja proporcionado desde a mais tenra idade o encorajamento necessário para aprender a conhecer, agir e pensar como cidadãos, construindo as bases para uma sociedade livre, justa e solidária.

Tendo em vista o cenário atual de crise institucional e de fragilidade democrática, decorrentes da ausência de uma educação cidadã, faz-se necessário enfrentar os problemas brasileiros por meio das críticas, bem como construir em conjunto com a sociedade e para esta, soluções que busquem mitigar o déficit emancipatório e mais que isso, que busquem estabelecer a instrumentalização necessária do brasileiro para uma mentalidade neoconstitucional. Ou seja, uma mentalidade, cuja vontade seja a busca pela efetivação máxima das proteções e direitos constitucionais.

É importante o fomento para uma cultura política democrática, com ações que venham a contemplar as demandas e interesses da maioria da população, levando os cidadãos a impulsionarem mudanças no cenário político e social, bem como a 
devida conscientização que o voto e a existência de instituições democráticas não garantem a cidadania se os cidadãos não forem os protagonistas desse processo.

Urge necessário no novo século em que o avanço tecnológico e as novas ferramentas de informação e comunicação se fazem presentes para uma otimização da participação direta do cidadão na vida pública de forma qualitativa, readequar, desenvolver e aprimorar a democracia para uma nova geração, por meio das mídias sociais.

No cenário contemporâneo, repleto de possibilidades e incertezas, eis que surgem informações reflexas a todo tempo, sobre as quais devem os indivíduos ser maduros e sagazes para captá-las e readequá-las ao nosso meio social como objeto motivador da cidadania e tendo no ciberespaço o meio facilitador e impulsionador à esta participação, desenvolvendo e aprimorando a democracia.

Ademais, a ausência de uma cultura constitucional direciona o país para o abismo do obscurantismo e extremismos, os quais passam a ser tolerados e disseminados como se corretos e legítimos fossem, penalizando não só as instituições democráticas, como também, o desenvolvimento social e humano.

Dessa forma, é imperioso fazer análises, tecer críticas e propor alternativas enfrentando o tema de pesquisa proposto, em decorrência da relevância social e o impacto causado pela ausência de uma cultura constitucional. De tal modo, se faz importante e necessário pensar em estratégias que direcionem e capacitem os atores jurídicos-políticos à concretização da Constituição de 1988 sem os entraves oriundos do neoliberalismo destrutivo, bem como cultivar no brasileiro, por meio da educação cidadã, a busca pelo desenvolvimento social como forma de mudar a realidade nacional.

\section{Metodologia}

Trata-se de uma análise, descrição e compreensão, a partir da legislação e doutrina, dos núcleos do problema desenvolvimento da cidadania brasileira cuja implantação de uma cultura neoconstitucional voltada para concretização da constituição de 1988 possibilite uma consciência nacional respaldada na dignidade humana, bem como sua efetivação pelos agentes políticos - e dos fenômenos e elementos que os envolvem. Assim, a pesquisa pretende reunir diferentes autores que abordam o tema, no intuito de trazer forma explícita e coerente respostas à problemática levantada.

Apresenta-se como pesquisa qualitativa com revisão de literatura, a qual faz uma análise aprofundada das ideias apresentadas nos livros, teses, dissertações e artigos utilizados e que deram origem ao trabalho. Tais instrumentos foram coletados a partir de extensa pesquisa bibliográfica, a qual abrangeu assuntos relacionados à democracia e cidadania brasileira, neoconstitucionalismo, as redes de comunicação e a efetividade da Constituição de 1988, bem como legislação pertinente à implantação de uma cultura constitucional a partir da educação básica. Após seleção do material e sua análise, que foi realizado de forma minuciosa, foi escolhido autores clássicos que abordaram a temática de modo atemporal (Bobbio, Kelsen, Habermas, Dallari, Bonavides, Benevides, Schumpeter, Freire, entre outros) bem como escolha de dissertações, teses e artigos escritos por autores de títulos de doutor ou mestrado

Sendo a metodologia qualitativa (Boaventura, 2004), extrai-se a essência e os assuntos mais relevantes para elucidar a problemática proposta, e consolidar ideias para fortalecimento de uma cultura nacional respaldada em valores humanos e voltada para a cidadania. O artigo de revisão de literatura, é considerado como tal, pois é formado por uma pesquisa de tipologia teórica, tendo como base obras de autores que tratam do tema abordado.

Buscando-se compreender um determinado fenômeno em profundidade a pesquisa qualitativa não trabalha com estatísticas e regras rígidas, mas realizando descrições, análises e interpretações de caráter subjetivo, características de uma pesquisa emergente e não estritamente pré-configurada. Dessa forma, na pesquisa qualitativa há a interação entre os elementos participantes, que podem orientar os caminhos, com o pesquisador. 
$\mathrm{Na}$ investigação qualitativa, trabalha-se com opiniões, representações, posicionamentos, crenças e atitudes, utilizandose procedimentos de cunho racional e intuitivo para melhor compreender a complexidade dos fenômenos individuais e coletivos. Dessa maneira, se caracteriza como uma abordagem de alto grau de complexidade, pois aprofunda as interpretações com o intuito de decifrar seus significados.

Pretende-se estruturar esta pesquisa fazendo considerações a respeito do direito à educação, neoconstitucionalismo, cidadania brasileira, democracia participativa, mídias sociais e efetivação dos direitos, garantias e deveres fundamentais como forma de possibilitar a dignidade humana e o desenvolvimento social.

\section{Resultados e Discussão}

O desenvolvimento no Brasil de modo efetivo depende de uma mudança de hábitos e mentalidades, que se traduz em manifesta exigência e consciência dos direitos e no exercício da cidadania participativa. A tradição brasileira, não é de "apego às virtudes políticas e, muito menos, de amor a igualdade" (Benevides, 1991, p. 193).

Desigualdade fundada não na estirpe (afinal, nossa "aristocracia" jamais teve reconhecidas origens históricas), mas na propriedade, no grande domínio rural que não podia subsistir sem a escravidão e vice-versa. A abolição da escravidão não introduziu o princípio da igualdade nas relações sociais e econômicas. Ao contrário, a dominação rural transportou-se para as cidades, passando a permear todas as relações sociais, econômicas, políticas e culturais. Tudo isso é conhecido - e já foi assaz discutido e analisado por tantos quantos pretendem entender os obstáculos à remoção das raízes antirrepublicanas e antidemocráticas no Brasil (Carvalho, 1999, p. 194).

É de se visualizar que os costumes brasileiros são um grande entrave para a legitimação da participação popular, a qual, segundo Benevides (1999), corresponde um verdadeiro remédio contra a tradição oligárquica e patrimonialista, sobrelevando a necessidade da educação como pressuposto básico para a cidadania ativa. A democratização efetiva no Brasil depende de uma mudança de hábitos e mentalidades, que se traduz em manifesta exigência e consciência dos direitos e no exercício da cidadania participativa.

A participação do brasileiro na vida política é extremamente deficiente, por conta da extensa desconfiança da população frente aos políticos, pertencentes às elites político-partidárias, dotados de imoralidade congênita, resultando em um foço cada vez mais profundo, entre os interesses públicos fundamentais previstos na Constituição Federal de 1988 e sua devida e necessária efetivação pelos representantes, gestores públicos. Há um problema de representatividade grave no Brasil, diante da desesperança geral do povo para enfrentar interesses egoísticos e escusos da classe política, e colidir com um sistema que patrocina a mercantilização do voto e a coisificação do sujeito.

O aspecto corrosivo do descrédito na classe política e instituições é explicado em Benevides (1991, p. 24/25):

A população brasileira, ontem como hoje, não se sente "bem representada" no Legislativo. O cidadão brasileiro pode ser ignorante e acreditar nos milagres de "um salvador da pátria". No outro extremo, pode ser politizado e participar dos movimentos populares na defesa dos interesses coletivos. Mas, decididamente, não confia nos "representantes" do povo. O que, sem dúvida, não é bom para a democracia (...). É justamente por isso que, ao meu ver, uma das deficiências mais sentidas na representação política no Brasil consiste na total ausência de responsabilidade efetiva dos representantes perante o povo (...).Aponta-se a representação distorcida, o coronelismo redivivo nas várias formas de clientelismo, o populismo de diversos matizes, o sistema eleitoral viciado e, ainda, o abuso do poder econômico nas campanhas eleitorais. O que compõe sem dúvida, um painel nas pouco animador da representação política, ao qual se agrega, consequentemente, aquela descrença na política e nos políticos.

A apatia social é caracterizada como um comodismo social frente ao Estado, e este, por seu lado tem a função de dar providências adequadas aos problemas da sociedade moderna. Infere deste modo, Rosenfield (2003, p. 77): 
O circuito podendo dar lugar a uma concepção ativa da cidadania rompe-se, de tal modo que o discurso político, cujas funções são as de exprimir o interesse geral, de reunir os indivíduos em torno de um mesmo projeto e de se constituir enquanto início de uma nova ação política, torna-se um mero "discurso burocrático". Apoderado sob um grupo social determinado que, sob a aparência do bem comum, veicula interesses particulares, este discurso termina por impedir o nascimento de uma ação verdadeiramente política, transformando-se em um laço ideológico que, de fato, isola os indivíduos um dos outros em vez de ligá-los.

A soberania popular não é consequência automática do processo democrático, pois necessita de meios hábeis que coíbam a infidelidade institucional, bem como a implantação de uma cultura democrática respaldada na ética, informação, consciência e educação.

Embora haja mecanismos institucionais da democracia semidireta, quais sejam: a iniciativa popular, que é o direito do cidadão comum de iniciar um processo legislativo, o referendo e plesbicito (art.14, incisos I, II e III, CRFB/1988), estes encontram entraves ao serem submetidos à reserva legal e aos ditames do art. 49, XV, CF/1988 (necessidade de outorga pelo Congresso Nacional). Conclui-se, Bonavides (2001, p. 112) que:

De último, na organização constitucional do País, em matéria participativa, tocante à elaboração de leis e atos normativos, somente metade da Constituição está sendo cumprida. A outra metade se acha represada, desativada, embalsamada na reserva legal do art. 14. Contudo, a segunda metade é mais importante, mais crucial, mais democrática que a primeira. Descurada, como tem sido até agora, faz do nosso sistema representativo um sistema de meia-legitimidade, meia-democracia, meia representatividade, ou, em termos equivalentes, um sistema semilegítimo, semidemocrático, semi-representativo.

O art. 14/CRFB possui uma dimensão representativa e outra democrática direta, sendo que está ultima está sujeita a reserva legal, o que para Bonavides (2001. p. 112) se torna um "instrumento das elites conservadoras, temerosas do governo popular direto, para refrear a expansão de uma presença mais ativa e imediata do corpo da cidadania na formação da vontade governativa", resultando em uma flagrante inconstitucionalidade material.

Esmiuça ainda, Bonavides (2001) que , faz-se mister entender os preceitos constitucionais como um conjunto unitário, em que todo seu arcabouço normativo precisa estar dialogando e se complementando, e deste modo, em um claro entendimento dos anseios do constituinte percebe-se que a democracia brasileira incorporou a participação popular como forma de legitimar as instituições políticas (artigo 1º, parágrafo único da CRFB). Assim, Bonavides (2001, p. 126) explica:

Doravante, consiste a inteligencia constitucional do art. 14 em movimentar a maquina do poder popular, sem tergiversar, sem se embaracar com os obstaculos de uma reserva de lei que, em verdade, o tempo e a supremacia do povo soberano fizeram caducar. Persistir noutro entendimento, isto, sim, há de configurar inconstitucionalidade gravissima, a pior das inconstitucionalidades: a inconstitucionalidade material, aquela que em sua manifestacao extrema abala regimes, subverte instituicoes, desfere golpes de Estado, corrompe a cidadania, promove crises constituintes, solapa o poder legitimo, desfigura o Estado de Direito, derranca o Estado Social e, fazendo ruir a soberania popular, faz a nacao dobrar os joelhos as ditaduras.(...) Obra, por igual, do egoísmo e da amaurose das elites, obstinadas na conservação de seus privilégios, dos quais não sabem nem querem recuar, essa inconstitucionalidade material se define, também, pela atitude dos juristas insensíveis aos métodos renovadores que conduzem a Constituição ao povo. E a conduzem de sorte que este seja colocado no pedestal de sua soberania: a soberania do cidadão governante, que não é a mesma do cidadão governado por representantes. As armas participativas contidas no texto do art. 14 da Lei Fundamental, como o plebiscito, o referendo e a iniciativa, não lhe podem ser negadas sem negar a soberania do povo e sem matar a alma do colégio constituinte que fez e promulgou a Carta Magna de 1988.

Violar os princípios basilares da Constituição Federal de 1988, é ofender a efetividade da Lei Maior e sua força normativa, golpeando o Estado democrático de Direito de modo fraudulento e silencioso. Reconhecendo a força normativa da Constituição a serviço da cidadania, dispõe Barroso (s/d, p. 5/6) que a doutrina brasileira: 
Procurou não apenas elaborar as categorias dogmáticas da normatividade constitucional, como também superar algumas das crônicas disfunções da formação nacional, que se materializavam na insinceridade normativa, no uso da Constituição como uma mistificação ideológica e na falta de determinação política em dar-lhe cumprimento. A essência da doutrina da efetividade é tornar as normas constitucionais aplicáveis direta e imediatamente, na extensão máxima de sua densidade normativa. (...) No plano jurídico, atribuiu normatividade plena à Constituição, que se tornou fonte de direitos e de obrigações, independentemente da intermediação do legislador. Do ponto de vista científico ou dogmático, reconheceu ao direito constitucional um objeto próprio e autônomo, estremando-o do discurso puramente político ou sociológico. E, por fim, sob o aspecto institucional, contribuiu para a ascensão do Poder Judiciário no Brasil, dando-lhe um papel mais destacado na concretização dos valores e dos direitos constitucionais. (...) A efetividade foi o rito de passagem do velho para o novo direito constitucional, fazendo com que a Constituição deixasse de ser uma miragem, com as honras de uma falsa supremacia, que não se traduzia em proveito para a cidadania.

Neste diapasão Cabral (p. 17/18) infere que:

Por sua vez, a democracia apresentou-se como forma de governo subserviente à realização do próprio existir humano. O poder do governo democrático não consiste tão-somente no cerceamento e balizamento de algumas ações humanas. Nada disso. Concebê-lo assim é aniquilar sua real dignidade. O poder democrático consiste na capacidade de favorecer a potencialização humana no que se refere ao partejamento de uma existência responsável pela totalidade dos entes e que torne-se, concomitantemente, livre. Esta é a razão ontológica que obriga o Estado democrático a sempre somar esforços para a superação das desigualdades sociais. Ora, se a democracia é uma forma de governo subserviente ao homem, ela nunca pode se determinar de forma absoluta, imutável. Pelo contrário, o governo democrático deve ter a mesma leveza presente na existência humana, que a cada momento muda para achar a forma adequada para melhor responder às suas dependências.

Ademais, a justiça dialoga intrinsecamente com valores morais, do que é justo ou injusto, impeditivo da degradação social e da mercantilização da pessoa humana, bem como suas relações, sendo os valores morais precedentes a própria lei positiva, sendo possível concluir que "numa palavra, a lei natural está escrita em nossos corações com caracteres tão bonitos, com expressões tão fortes e traços tão luminosos que não é possível desconhecê-los” (Diderot, apud Rosenfield, 1994, p. 52).

É imperioso compreender, conforme Barroso (2017) que o Direito passou a ser objeto de ampla e inacabada reflexão na busca de sua função social e melhor interpretação, superando-se fracasso político do positivismo. Nesse ínterim, o póspositivismo caminha além da legalidade estrita procurando empreender uma leitura moral do Direito. O reconhecimento de normatividade aos princípios e sua distinção qualitativa em relação às regras é um dos legados do pós-positivismo. Princípios, diferentemente das regras (comandos imediatamente descritivos de condutas específicas), são normas que consagram determinados valores ou indicam fins públicos a serem realizados por diferentes meios.

A interpretação e aplicação do ordenamento jurídico hão de ser inspiradas por uma teoria de justiça, atribuindo normatividade aos princípios e a definição de suas relações com valores e regras, a formação de uma nova hermenêutica constitucional e o desenvolvimento de uma teoria dos direitos fundamentais edificada sobre o fundamento da dignidade humana, promovendo-se uma reaproximação entre o Direito e a Filosofia.

Uma das grandes mudanças de paradigma ocorridas ao longo do século XX foi a atribuição à norma constitucional do status de norma jurídica. Superou-se, assim, o modelo que vigorou na Europa até meados do século passado, no qual a Constituição era vista como um documento essencialmente político, um convite à atuação dos Poderes Públicos. A concretização de suas propostas ficava invariavelmente condicionada à liberdade de conformação do legislador ou à discricionariedade do administrador. Ao Judiciário não se reconhecia qualquer papel relevante na realização do conteúdo da Constituição. (...)Uma das grandes mudanças de paradigma ocorridas ao longo do século XX foi a atribuição à norma constitucional do status de norma jurídica. Superou-se, assim, o modelo que vigorou na Europa até meados do século passado, no qual a Constituição era vista como um documento essencialmente político, um convite à atuação dos Poderes Públicos. A concretização de suas propostas ficava invariavelmente condicionada à liberdade de conformação do legislador ou à discricionariedade do administrador. Ao Judiciário não se reconhecia qualquer papel relevante na realização do conteúdo da Constituição. (Barroso, 2017, p.7) 
Nesse sentido, informa Barroso (2017) que o debate sobre força normativa da Constituição só chegou ao Brasil, de maneira consistente, ao longo da década de 1980, tendo enfrentado resistências previsíveis. O País possuía complexidades inerentes à concretização de qualquer ordem jurídica, bem como padecia de patologias crônicas, ligadas ao autoritarismo e à insinceridade constitucional. Estas eram apenas repositórios de promessas vagas e de exortações ao legislador infraconstitucional, sem aplicabilidade direta e imediata. O dever de rompimento dessa postura, coube à Constituição de 1988, bem como à doutrina e à jurisprudência que se produziram a partir de sua promulgação.

Coni e Dantas (2017) sustentam que todo o aparato democrático e demais garantias fundamentais, só fazem sentido se priorizar o cidadão e estiverem focadas na garantia do exercício da cidadania, "cabendo ao Estado promover ações sociais cada vez mais voltadas ao bem comum, objetivando a realização de uma justiça social concreta, de modo a promover a interação dos cidadãos com a democracia" (Coni \& Dantas, 2017, p. 52).

Assim, a cidadania brasileira por vezes configurar-se ineficiente, seja por falta de uma cultura democrática lapidada por uma educação inclusiva, seja pela falta do cumprimento dos requisitos do artigo 37 da CF/1988 (legalidade, impessoalidade, moralidade, publicidade e eficiência) pelos gestores públicos, ou seja pela falta de uma interpretação coerente da Constituição, contradiz com o seu espirito principiológico e sua força normativa à satisfação dos direitos humanos básicos à sua existência digna.

A educação é o ponto de partida para integrar e organizar a sociedade, possibilitando sua influência em decisões relevantes pelos gestores públicos e corrigindo a involução participativa do regime democrático brasileiro.

É evidente que, com a evolução do Estado moderno, o exercício do governo inclui cada vez mais tarefas complexas e técnicas, contribuindo para o estabelecimento de uma relação autoritária entre governantes e governados. Essa relação é sabido, tem provocado várias consequências negativas desde a indiferença até a franca hostilidade do povo para com os políticos, em geral, e para os governantes, em particular. (Benevides, 1991, p. 196)

O excesso de tecnicismo que direcionam as ações estatais (Benevides, 1991), não deve ser uma barreira ao exercício da cidadania nem pretexto para os atores jurídicos-políticos não se empenharem na concretização da Constituição de 1988, mas deve ser, o impulso necessário a proporcionar medidas governamentais capazes de sanar a deficiência técnica do cidadão comum, o qual deve ser atuante na sociedade em que se encontra.

Para Bobbio (1997) a prática democrática daria os instrumentos necessários para o processo de educação política:

A participação eleitoral tem um grande valor educativo; é através da discussão política que o operário, cujo trabalho é repetitivo e concentrado no horizonte limitado da fábrica, consegue compreender a conexão existente entre eventos distantes e o seu interesse pessoal e estabelecer relações com cidadãos diversos daqueles com os quais mantém relações cotidianas, tornando-se assim membro consciente de uma comunidade. (Mill, 1982 apud Bobbio, 1997, p. 32)

A educação fornece a liberdade necessária ao indivíduo, dando-lhe discernimento e responsabilidade necessários às suas escolhas, sendo o primeiro passo para a efetiva participação e exercício da cidadania o despertar da consciência individual, e só assim resultaria em mudanças profundas na sociedade, pois conforme Dallari $(1984$, p. 43) "o indivíduo conscientizado não fica indiferente e não desanima perante os obstáculos. Para ele a participação é um compromisso de vida exigida como um direito e procurada como uma necessidade".

Desse modo, a humanidade será beneficiada na medida em que desperta o ser humano a pensar e agir em defesa de sua dignidade ao mesmo tempo que faz com que ele busque melhorias para a sociedade de uma forma geral. A educação que estimule a conscientização contribui para que as pessoas percebam que nenhum ser humano tem mais valor que outro, e que toda luta que busque a transformação e amadurecimento das relações humanas, seja ela política, econômica, social ou cultural, é legítima. A dignidade humana jamais poderá ser objeto de negociação, aduzindo Dallari (1984, p. 52): 
Pode-se trabalhar pela conscientização em sentido mais amplo, apenas estimulando pessoas ao uso da inteligência e da vontade, para não se deixarem usar e conduzir como seres irracionais. (...) Ou se pode promover a conscientização relativamente a determinadas situações ou em função de certos objetivos. Essa hipótese se verifica quando alguém está sendo usado para a promoção ou manutenção de injustiças e não percebe que é isso que está ocorrendo. É exatamente essa a situação do professor que ou da professora que ensina os seus alunos a aceitarem passivamente as decisões do governo, a elogiarem sempre os governantes e a nunca se rebelarem contra a ordem estabelecida, sem indagar se esta é justa ou injusta. Esses professores geralmente agem assim porque são inconscientes.

Conscientizar uma pessoa é ajudá-la a fugir da alienação e despertá-la para o uso da razão, dando-lhes condições para que perceba as exigências morais da natureza humana. A nova dimensão do constitucionalismo caracterizada enquanto movimento de luta pela defesa dos direitos fundamentais e pela limitação do exercício do poder é consubstanciada por um intenso combate contra o poder econômico e político, na busca incessante "por democracia, liberdades, dignidade, saúde, educação, transporte, moradia, trabalho e para que sejam efetivados de forma suficientemente satisfatória" (Coni \& Dantas, 2017, p. 49).

Dantas (2011), expõe que para a efetiva auto realização e pleno desenvolvimento da personalidade em favor dos membros da comunidade política, precisa-se que a constituição seja dotada de força normativa e impositiva à transformação da realidade. É neste constitucionalismo social que desenvolveu a teoria da constituição dirigente, que reconhece o caráter normativo da constituição como um todo, que goza de imperatividade e supremacia, assim, "a constituição dirigente assume como tarefa a transformação da realidade" (Canotilho, 2001, p. 70 apud Dantas, 2011, p. 97).

A Constituição de 1988 é dirigente e está pautada no Estado Democrático de Direito e busca atender e efetivar os direitos fundamentais. Contudo, como asseverou Dantas (2009), o dirigismo constitucional brasileiro tem sofrido represálias e pressão de todas as ordens, que tentam mitigar a carga emancipatória e o conteúdo dirigente referente a solidariedade e dignidade. Assim, identifica Dantas (2009, p. 251/252):

A previsão de uma Constituição plasmada em direitos fundamentais, dentre os quais vários direitos sociais, instituidora do Estado Democrático de Direito de coloração republicana, fundada na solidariedade social dirigida e dirigente para a diginidade da pessoa humana através dos objetivos fundamentais consagrados enquanto projeção comunitária do sentido do futuro, não é a panaceia para todos os males sociais e nem a solução para o exercício arbitrário do poder político.

A Constituição nada garante, se a coletividade não assume seu papel comunitário, cujo pertencimento deve integrar os sujeitos constituintes "partícipes da realização dos direitos fundamentais e dos objetivos contitucionais programaticos previstos" (Dantas, 2009, p. 252). Logo, o Estado Democrático de Direito, não pode se opor e se externar à comunidade, uma vez que, a satisfação desta é sua finalidade pressípua. Reverbera Barroso (s/d , p. 22) que "o valor comunitário constitui o elemento social da dignidade humana, o indivíduo em relação ao grupo. Aqui, a dignidade é moldada pelos valores compartilhados pela comunidade, seus padrões civilizatórios, seu ideal de vida boa”.

A Constituição Federal brasileira em seu art. $6^{\circ}$ cuida dos direitos fundamentais, declarando como direitos sociais a educação, a saúde, a alimentação, o trabalho, a moradia, o lazer, a segurança, a previdência social, a proteção à maternidade e à infância, a assistência aos desamparados. Oportuno asseverar que a própria ordem econômica nacional, está respaldada nos ditames da justiça social com a valorização do trabalho humano, livre iniciativa e a garantia de vida digna a todos $(\mathrm{CF} / 1988$, art. 170).

A ordem jurídica nacional está orientada pelos preceitos do direito social, cuja distribuição de riqueza, resultante da justiça social, a efetivação da democracia e a valoração, elevação e preservação da condição humana, são requisitos básicos e condicionantes para a paz social e mundial, em um relevante papel de reforma da realidade. Declara Maior (2013, p. 82) que: 
A função do direito social é distribuir a riqueza, para fins não apenas de eliminar, por benevolência, a pobreza, mas para compor o projeto de uma sociedade na qual todos possam, efetivamente, adquirir, em sua significação máxima, o sentido da cidadania, experimentando a beleza da condição humana, sendo certo que um dos maiores problemas que agridem a humanidade é a injustiça.

Conforme Barroso (s/d, p. 22) "todo indivíduo precisa ter satisfeitas as necessidades indispensáveis à sua existência física e psíquica”, que nada mais é, que a efetivação dos direitos fundamentais sociais e suas pré-condições básicas, quais sejam, os direitos individuais e políticos, da autonomia privada e pública.

Infere-se que onde há uma sociedade que se respalda nos direitos humanos, há uma maior efetivação dos direitos por conta da opinião e pressão pública que caminham neste sentido. Deste modo, aduz Limberger (2016, p. 34) que "somente quando os direitos humanos se encontram inscritos na consciência dos homens e dos povos atuam como instâncias de conduta, às quais se possam recorrer".

Impugnando por uma formação humana, aduz Habermas (1988, p. 265 apud Limberger, 2016, p. 36/37) que, “a cultura política das sociedades democráticas do presente deve fazer-se solidária, contínua e tem de representar a plena realização dos valores ilustrados da razão, liberdade, igualdade e fraternidade universal".

Freire (2001) informa que é preciso desenvolver a consciência crítica, pois é somente por ela que o indivíduo entende e se integra a realidade e ao contexto, e afasta-se da consciência mágica-fatalista e da consciência fanática. Somente por um método ativo, dialogal, crítico e criticizador, seria possível educar uma sociedade para o exercício da cidadania, e enfrentar um contexto histórico cujo sentido caminha para uma direção contrária.

Assevera Limberger (2016, p. 38) sobre o mecanismo de auto implementação entre os recursos públicos e o investimento nos direitos sociais:

Com melhor gerenciamento dos recursos públicos e menores índices de desvio, possibilita-se o investimento para custear os direitos sociais, permitindo-se sua efetividade. (...) Se há o correto gasto e investimento dos recursos públicos, atinente aos direitos sociais, ocorrerá maior ingresso de verbas na área da educação. Se esta é fortalecida, maiores os níveis de formação cultural da população e, portanto, mais condições de fiscalização, por meio dos dispositivos de disponibilização das informações públicas na internet. Trata-se de mecanismo que corrobora sua gestão com as inversões adequadas nos serviços públicos relacionados com a educação e a formação cidadã, que, posteriormente, os fiscalizará e contribuirá para futuros investimentos.

Coni e Dantas (2017) sustenta que todo o aparato democrático e demais garantias fundamentais, só fazem sentido se priorizar o cidadão e estiverem focadas na garantia do exercício da cidadania, "cabendo ao Estado promover ações sociais cada vez mais voltadas ao bem comum, objetivando a realização de uma justiça social concreta, de modo a promover a interação dos cidadãos com a democracia" (Coni \& Dantas 2017, p. 52).

A Constituição Federal de 1988 é uma Carta Magna de caráter político, jurídico e social, dotada de normatividade, ou seja, de efetividade. Assim, sua concretização não deve ser discricionariedade do Estado, mas um dever, uma responsabilidade intrínseca para o desenvolvimento do País por intermédio de políticas públicas eficientes e verdadeiras.

No entanto, essas políticas públicas só serão cobradas e fiscalizadas, se o brasileiro age ativamente na busca do desenvolvimento social e se ele compreende e tem como valor os princípios de liberdade e de solidariedade humana. Quando esses princípios são relativizados e/ou ausentes, todo o resto encontrar-se-á prejudicado. Por isso, é preciso extrair esses valores da consciência individual a partir do ensino básico alinhando com os valores que guiam a sociedade, informados no texto constitucional. O incentivo ao aprendizado da Constituição Federal de 1988 ocasionará, posteriormente, melhores legisladores, governantes, membros do poder judiciário e da sociedade como um todo.

A educação e os espaços de aprendizagem são de extrema importância para formação do cidadão (Lei nº 9.394/96, art. 22), e por isso, a inclusão de uma disciplina nas grades curriculares do ensino básico, que forneça as noções elementares do 
que é uma constituição, sua importância, seus princípios e fundamentos, os direitos e deveres do cidadão e como este cidadão poderá ser defensor da Lei Maior e do Estado Democrático de Direito, se faz urgente e necessário, pois asseguram a vida digna. Se a sociedade não consegue compreender os preceitos constitucionais, dificilmente atingirá os objetivos e finalidade do país.

Dessa forma, ao adicionar o estudo da Constituição de 1988 nas escolas, públicas e privadas do país, será removida uma lacuna na formação ética e política, fornecendo, principalmente, o conhecimento sobre as noções básicas da cidadania e a finalidade da Constituição Federal de 1988.

Assegurar o exercício dos direitos sociais e individuais, a liberdade, a segurança, o bem-estar, o desenvolvimento, a igualdade e a justiça como valores supremos de uma sociedade fraterna, pluralista e sem preconceitos, fundada na harmonia social e comprometida, na ordem interna e internacional, com a solução pacífica das controvérsias. (Preâmbulo, CRFB/1988)

Alguns Projetos de Lei foram elaborados nesse sentido a nível nacional (Projeto de Lei $n^{\circ} 38 / 2015$ e Projeto de Lei ${ }^{\circ}$ 70 de 2015), bem como a nível estadual (a exemplo do Município de Minas Gerais o qual aprovou a inclusão do ensino da Constituição Federal na grade curricular do ensino fundamental). No entanto, tais estímulos não ganharam a adesão social e política necessária.

Em junho de 2015 foi lançada no $25^{\circ}$ encontro da Associação Brasileira das Escolas do Legislativo e de Contas ABEL, em Vitória, a Constituição em Miúdos. Trata-se de um projeto que visa à conscientização dos estudantes acerca dos direitos e garantias fundamentais contidos na Carta Magna brasileira. A partir de então, Estados e Municípios têm implantado temática na rede pública de ensino.

Segundo o professor Evandro F. Capano, “educar para a cidadania consiste no processo formativo que tornará apto o educando a participar da tomada da decisão política, seja reivindicando direitos, seja tomando parte diretamente na condução da sociedade, fortalecendo assim o nível da democracia no Estado" (CAPANO 2013). Logo, é fundamental que a Constituição federal, como lei maior do estado seja ensinada durante a formação básica de cidadão. (Projeto De Lei $\left.N^{\circ} 0192 / 2019-A L\right)$

Contudo, embora haja essa tímida iniciativa por alguns Estados, falta uma coesão nacional para obtenção de resultados práticos através de medidas legislativas e políticas públicas nacionais, que não só dê qualidade e universalidade à educação básica, com uma escola atrativa, humanizada e moderna, mas que implemente nela o ensino da Constituição Federal de 1988, sem inchar a grade curricular e fornecendo aprendizado que permita que os jovens se sintam seguros para "reivindicar os seus direitos, e reconhecer que direitos implicam obrigações. Deve promover o respeito para com a lei, a justiça e a democracia. Alimentar o interesse pelo bem comum, ao mesmo tempo que incentivar a independência do pensamento" (Constituição Em Miúdos).

Coni e Dantas (2017), esclarecem que o grande problema brasileiro, não é a extensão/limite dos recursos públicos, mas sim a sua má gestão pelos administradores públicos “que em sua grande maioria, deixam de observar as regras básicas de gestão e governança no trato dos recursos, ensejando ao final inefetividade de políticas públicas e serviços precários para os cidadãos" (Coni \& Dantas, 2017, p.15).

A população deve ser preparada através de políticas públicas educacionais, para poder ter a cognição necessária à compreensão das informações prestadas por uma gestão transparente, no sentido de poder exercer todas as prerrogativas da cidadania. Além disso, é somente compreendendo criticamente as ideologias partidárias, tendo poder de análise, tanto do perfil como do histórico dos candidatos, é que o cidadão poderá ser completo e racional. E isso só é possível através da educação.

No Brasil, conforme pesquisa realizada pelo Instituto Brasileiro de Geografia e Estatística-IBGE (2019) atesta que em 2019, 48,8\% de pessoas com 25 anos ou mais, concluíram o ensino médio; e que 46,6\% da população de 25 anos ou mais 
possuem o nível de instrução até o ensino fundamental completo ou equivalente; 27,4\% tinham o ensino médio completo ou equivalente; e $17,4 \%$, o superior completo.

$\mathrm{O}$ acesso à Educação de qualidade é direito fundamental para o desenvolvimento da cidadania e ampliação da democracia. Os investimentos públicos em educação são de extrema importância para a redução da pobreza, criminalidade e ampliação do crescimento econômico, bem-estar e acesso aos direitos fundamentais pela população (IBGE, 2019).

Em entrevista concedida Ramal (2018) informa que a taxa de analfabetismo ainda existente, é um escândalo social que coloca o Brasil em risco, inclusive no desenvolvimento do potencial econômico. Ainda, impugna que o estudo aumenta a autoestima das pessoas, que quando não sabem ler, não sabem escrever, não sabem fazer uma leitura do mundo, se sentem excluídos e sem importância. Assim, só o estudo é capaz de mostrar a importância de cada indivíduo, o qual através do conhecimento adquirido terá a consciência que possui uma voz e uma vez.

Então, de nada adiantaria uma maciça quantidade de informações e conteúdo para apreciação da população, se esta não possui uma educação mínima para ler, analisar e interpretar os dados fornecidos pelos gestores. Coni \& Dantas (2017, p. 114) dispõem:

Em paralelo, faz-se mister, ainda desenvolver programas para qualificar a alfabetização, para que os já aptos a ler e escrever, possam na prática efetivamente compreender o que estão lendo, para melhor tratar as informações disponibilizadas. Com alfabetização de qualidade e compreensão dos dados, das informações e dos aspectos políticos, econômicos e sociais, a população estará apta e empoderada à participação nas definições dos rumos da gestão estatal, tornando-se efetivos cidadãos, especialmente se contarem com o auxílio dos meios digitais e sua ampla divulgação e circularidade.

Acrescente-se a isto, a necessidade nacional de desenvolver uma cultura cívica, que oriente a cada pessoa a imprescindibilidade de abraçar o interesse público como se individual fosse. A formação cultural é imprescindível, conforme Limberger (2016), para o desenvolvimento individual e de um país. Somente com a educação, é possível consolidar e exercer os valores democráticos e éticos.

Nesse diapasão, a vontade popular não pode ser pré-fabricada, fruto da mercantilização do processo democrático e dos negócios dos votos, com vontade artificialmente fabricada, "em que os fatos e a vontade popular sobre qualquer assunto são manipulados" (Schumpeter, 1961, p. 321), utilizando-se dos métodos da publicidade para adestrar e adormecer as faculdades críticas do povo.

A opinião pública em uma sociedade de massas, cujo individuo, suas ideias, a criticidade, o raciocínio, são irrelevantes e subjugados por paixões, é um produto industrial manufaturado que favorece as idiossincrasias dos governantes e por consequência traduz-se em uma opinião pública irracional.

Bonavides (2012) desenvolve o conceito da opinião pública atual como uma definição das ideias previamente recebidas de forma parcial, unilateral, falha, e imperfeita acerca dos fatos. Acrescenta que a deformação da opinião esclarecida também se agrega ao fato do Estado ter um volume alto de atividades e por isso necessitar de um corpo técnico e especializado, cujas massas não estão possibilitadas a possuir, pois não possuem a dimensão total dos problemas tornando-as apenas receptores passivos das ideologias governamentais. Conclui ao afirmar que a técnica utilizada em meios de comunicação (imprensa, rádio e televisão) age como meio propulsor do pensamento pré-moldado, ao encurtar a distância entre os indivíduos e os centros formadores de opinião pública.

A democracia não possui o processo de formação de opinião tipicamente hierárquico, mas por óbvio, a existência de um sistema educacional que não seja de doutrinação e uma estruturação policêntrica dos meios de comunicação possibilitaria uma opinião pública livre e independente, ou seja, autônoma. Segundo Sartori (1994), a multiplicidade competitiva dos meios 
de comunicação deveria estar acompanhada de uma otimização das informações para poder ensejar uma opinião verdadeiramente autônoma.

Habermas (1997) estabelece a importância do princípio do discurso no que tange a formação da opinião pública, para o conhecimento das informações e argumentos para que sejam aceitos ou não, de uma forma racional e para que, na prática haja o entendimento e a compreensão entre os discursos e vontades. Segundo Habermas (1997, p. 191) "o poder comunicativo de conviçções comuns só podem surgir de estrutura de intersubjetividade intacta", ou seja, isentas de violência.

Conclui-se do entendimento Harbermasiano que, para uma formação política racional da vontade, é preciso haver deliberações que promovam o discernimento e a ponderação da vontade coletiva e que possibilitem estratégias para alcançar a esta finalidade, bem como, é necessário haver uma orientação valorativa para o autoentendimento.

Outrossim, Habermas (1997, p. 171) aduz que os "direitos fundamentais criam as condições para iguais pretensões à participação em processos legislativos democráticos" na medida que o poder politicamente organizado na forma do legislativo necessita de um poder executivo que funcione e implemente o programa acordado, o qual só possui a abrangência estatal prevista se a sociedade se serve do direito de participação para poder influenciar as ações do poder político.

A vontade artificialmente criada está intrinsecamente ligada ao fato do povo estar movido por paixões para as tomadas de decisões públicas que o impedem de visualizar as diversas situações problemáticas do país com mais clareza e racionalidade, conforme o entendimento extraído de Schumpeter (1961). Porém, é válido ressaltar, que se não fosse a indignação pelas formas tradicionais de governança, em nada seria modificado e abalado as estruturas que desumanizam a cidadania. E a indignação nada mais é do que uma partícula do conjunto de emoções humanas.

Castells (2016, p. 162), aduz que:

De fato, a mudança social envolve uma ação individual e/ou coletiva que é, em sua essência, emocionalmente motivada, da mesma forma que todo comportamento humano, segundo recente pesquisa em neurociência. No contexto das seis emoções básicas identificadas por neuropsicólogos (medo, aversão, surpresa, tristeza, felicidade e raiva), a teoria da inteligência afetiva em comunicação política argumenta que o gatilho é a raiva, e o opressor, o medo.

Frise-se que, os motores da emoção que despertam o cidadão à participação são essenciais para o ponto de saída, sendo nebuloso inferir se tal efervescência emotiva continuará a contribuir no momento em que os resultados almejados são conquistados pelos movimentos sociais, ou se é necessário o equilíbrio emocional advindo com a racionalidade para melhor deliberar sobre estes resultados. É inconcluso afirmar algo neste sentido, pois, segundo Castells (2016, p. 179):

É muito cedo para avaliar o resultado final desses movimentos, embora já possamos dizer que regimes mudaram, instituições foram desafiadas e a crença no capitalismo financeiro global triunfante foi abalada, possivelmente de maneira irreversível, na mente da maioria das pessoas.

O histórico nacional está contextualizado em uma cidadania que titubeou, e ainda titubeia, em um misto de esperanças e incertezas. Conforme as informações extraídas de Carvalho (2002, p.18), os portugueses que aqui colonizaram deixaram uma "população analfabeta, uma sociedade escravocrata, uma economia monocultora e latifundiária, um Estado absolutista", o que impediu, no início, a existência de cidadãos brasileiros, e posteriormente, dificultou uma cidadania menos conflituosa e mais participativa. A colonização do Brasil foi fruto de uma miscigenação perversa e discriminatória, e os nacionais que aí se formaram, resultaram do estupro, da dominação e da ignorância.

Não havia o sentido de cidadania entre os nacionais que aqui se formaram. Os próprios senhores, os considerados "homens-bons", deturpavam o sentido ao ignorar a igualdade de todos e absorverem as funções típicas do Estado. Nestes termos, Carvalho (2002, p. 20/21) ensina que: 
Miscigenar era uma necessidade individual e política. A miscigenação se deu em parte por aceitação das mulheres indígenas, em parte pelo simples estupro. No caso das escravas africanas, o estupro era a regra. Escravidão e grande propriedade não constituíam ambiente favorável à formação de futuros cidadãos. (...) Entre escravos e senhores, existia uma população legalmente livre, mas a que faltavam quase todas as condições para o exercício dos direitos civis, sobretudo a educação. Ela dependia dos grandes proprietários para morar, trabalhar e defender-se contra o arbítrio do governo e de outros proprietários. Os que fugiam para o interior do país viviam isolados de toda convivência social, transformando-se, eventualmente, eles próprios em grandes proprietários. Não se pode dizer que os senhores fossem cidadãos. (...) Em suas mãos, a justiça, que, como vimos, é a principal garantia dos direitos civis, tornava-se simples instrumento do poder pessoal. O poder do governo terminava na porteira das grandes fazendas.

Desta forma, diante da escassez ou carência dos direitos civis, políticos e sociais, não é possível falar em cidadania no Brasil, ainda. Embora os direitos políticos tenham ganhado destaque quando da primeira Constituição nacional (1824), representando um avanço formal, ampliando a quantidade de votantes, na prática, aquela mesma população inicial se fazia presente, inferindo Carvalho (2001, p. 32):

Mais de $85 \%$ eram analfabetos, incapazes de ler um jornal, um decreto do governo, um alvará da justiça, uma postura municipal. Entre os analfabetos incluíam-se muitos dos grandes proprietários rurais. Mais de $90 \%$ da população vivia em áreas rurais, sob o controle ou a influência dos grandes proprietários. Nas cidades, muitos votantes eram funcionários públicos controlados pelo governo.

No Brasil, o voto ganhou significado equivocado, pois segundo Carvalho (2001) não fora um direito de participar da política nacional, mas tão somente uma ação que tinha íntima relação com as lutas locais, em que os votantes eram extremamente dependentes de um chefe local, devendo-lhe obediência, ou simplesmente motivado pelo sentimento de lealdade de gratidão. O chefe local, por sua vez, retribuía o voto ganhado com pagamentos (dinheiro, roupa, alimentos, animais, etc.), em uma típica relação de clientela e paternalista.

A população recém-saída da dominação portuguesa, não iria repentinamente se comportar como cidadãos atenienses ou os cidadãos das pequenas cidades norte-americanas. Conforme Carvalho (2001) o Brasil não passou por uma Revolução como na Inglaterra, Estados Unidos e França, assim, o processo de aprendizagem democrática seria lento e gradual. Além disso, tanto o povo, como a elite, como o governo eram extremamente despreparados para uma democracia. De acordo com Carvalho (2001, p. 43) é um equívoco achar que “o aprendizado do exercício dos direitos políticos pudesse ser feito por outra maneira que não sua prática continuada e um esforço por parte do governo de difundir a educação primária".

No Brasil não havia um povo politicamente organizado, opinião pública ativa, e eleitorado amplo e esclarecido, ainda que tivessem existido alguns movimentos políticos restritos e/ou locais, e um protótipo de sentimento nacional ainda que difuso. Até 1930 não havia sentimento nacional consolidado nem povo organizado politicamente. O sentimento nacional é prérequisito à cidadania. Carvalho (2002, p. 67) alega que avaliar o "povo como incapaz de discernimento político, como apático, incompetente, corrompível, enganável" é não perceber ou distorcer o fato de que a população até então não acostumada com a cidadania, não poderia modificar seus hábitos enraizados de forma rápida e efetiva.

A partir de 1930, Carvalho (2001), informa que com a urbanização nacional e a industrialização, houve a formação de identidade nacional na medida em que a participação popular tornou-se real, acelerando o processo de mudanças sociais e políticas, não obstante a existência de grandes problemas gerenciais e financeiros que dificultam até hoje a implementação dos direitos sociais, e a existência de instabilidades no meio político, o qual se alterna em ditaduras e regimes democráticos. Quanto aos direitos civis, estes progrediram lentamente, e com certa precariedade na prática para a maioria dos cidadãos, principalmente nos períodos ditatoriais.

Vale ratificar que o período datado de 1964 a 1985, foi de supressão de direitos civis e políticos, configurado pela repressão dos Governos Militares e de grande perda para as instituições democráticas. A queda dos governos militares deu-se com significativa participação popular, em que tiveram um meio capaz de possibilitar as "condições para a ampla mobilização 
e organização social que aconteceram após 1974." (Carvalho, 2002, p. 192), desembocando, por conseguinte, na redemocratização e na constituinte de 1988. Trazendo à vida política brasileira, a Constituição de 1988, apelidada como Constituição Cidadã, tem como pressupostos basilares o prestigio à democracia, a prevalência dos direitos humanos, a liberdade e a igualdade, a educação, saúde, trabalho, moradia, entre muitos outros direitos que são necessários para a dignidade humana e para a construção de uma sociedade livre, justa e solidária.

Sobre a cidadania brasileira ao longo da história nacional, frise-se que a influência escravocrata perpetua até hoje desde a estrutura arquitetônica das cidades até as relações interpessoais, tendo o Estado por vezes, interferindo com ações afirmativas. No Brasil, não houve um fomento à inclusão dessas pessoas à margem da sociedade após a abolição. Nem mesmo houve uma conscientização no que tange aos direitos. Dessa forma, a participação cidadã configurou prejudicada, seja por não desenvolver um ideal de homogeneidade nacional, seja porque manteve as velhas estruturas sociais.

As consequências da escravidão atingiram a todos, no que tange a formação da mentalidade cidadã. A extrema desigualdade entre senhores e escravos não foi sanada após a Lei Áurea, refletindo drasticamente na realidade atual brasileira em que os "privilégios e arrogância de poucos correspondem o desfavorecimento e a humilhação de muitos" (Carvalho, 2002, p. 53).

Da mesma forma, outro grande obstáculo à cidadania brasileira conforme Carvalho (2002) é: a intensa concentração de terras, desigualdade econômica e desemprego, resquícios da herança colonial; a preferência nacional pelo Executivo, decorrente na mentalidade infantilizada do brasileiro na escolha de políticos de caráter messiânicos e impulsos populistas; os problemas na área social (educação, saúde, saneamento); os problemas econômicos, orientados, inclusive, pela economia internacional; e um agravamento da situação dos direitos civis no que diz respeito à segurança. Todos esses fatores deixam a democracia brasileira instável e em constante efervescência popular, seja de uns contra os outros, seja de determinados grupos frente ao Estado. Elucida Carvalho (2002, p. 219):

Percorremos um longo caminho, 178 anos de história do esforço para construir o cidadão brasileiro. Chegamos ao final da jornada com a sensação desconfortável de incompletude. Os progressos feitos são inegáveis, mas foram lentos e não escondem o longo caminho que ainda falta percorrer. O triunfalismo exibido nas celebrações oficiais dos 500 anos da conquista da terra pelos portugueses não consegue ocultar o drama dos milhões de pobres, de desempregados, de analfabetos e semianalfabetos, de vítimas da violência particular e oficial. Não há indícios de saudosismo em relação à ditadura militar, mas perdeu-se a crença de que a democracia política resolveria com rapidez os problemas da pobreza e da desigualdade.

Após a redemocratização a prática política tem mostrado que há uma força das grandes corporações de banqueiros, comerciantes, industriais, das centrais operárias, dos empregados públicos, que buscam cada vez mais defender e aumentar os privilégios, ou buscar novos favores. Carvalho (2002) mostra que determinados grupos passaram a se organizar para garantir direitos e privilégios de forma corporativa, enquanto que a organização autônoma da sociedade resta prejudicada e ausente.

Benevides (1991) sintetiza o caminho histórico político no Brasil como reflexo das divergências teóricas e práticas, entre ideias liberais, democráticas e participacionistas e as ideias autoritárias, elitistas e corporativas. Os que são a favor da representação como exclusividade parlamentar e os que defendem a extensão da cidadania e a radicalidade da soberania popular. Por outro lado, os que não apoiam a representação, possuem um posicionamento que abrange desde o autoritarismo do Estado forte e centralizado, na figura de um chefe carismático, até o elitismo da representação, com a política dos notáveis, da elite intelectual e econômica.

Coadunando com esta afirmativa, Bobbio (1997) menciona uma ocorrência histórica:

Mas não posso deixar de pensar em Tocqueville que, num discurso à Câmara dos Deputados (em 27 de janeiro de 1848), lamentando a degeneração dos costumes públicos em decorrência da qual "as opiniões, os sentimentos, as 
ideias comuns são cada vez mais substituídas pelos interesses particulares", perguntava-se "se não havia aumentado o número dos que votam por interesses pessoais e diminuído o voto de quem vota à base de uma opinião política", denunciando esta tendência como expressão de uma "moral baixa e vulgar" segundo a qual "quem usufrui dos direitos políticos pensa em deles fazer um uso pessoal em função do próprio interesse".

Independentemente das soluções ofertadas de reformas (eleitoral, política, forma de governo), a recente democracia brasileira necessita de tempo para se estabilizar e ter as correções necessárias para seu aperfeiçoamento e consolidação. Carvalho (2002, p. 225) alega que: "para isso tem contribuído o ambiente internacional, hoje totalmente desfavorável a golpes de Estado e governos autoritários. Isso não é mérito brasileiro, mas pode ajudar a desencorajar possíveis golpistas e a ganhar tempo para a democracia".

Contudo, assevera Carvalho (2002), que o cenário internacional também traz complicações para a construção da cidadania, uma vez que o pensamento neoliberal enaltece a importância do mercado como mecanismo auto regulador da vida econômica e social, diminuindo significativamente o papel do Estado, e sua ingerência principalmente nos direitos sociais, e produzido um cidadão cada vez mais um consumidor e afastado de preocupações com a política e com os problemas coletivos.

A cultura do consumo dificulta o desatamento do nó que torna tão lenta a marcha da cidadania entre nós, qual seja, a incapacidade do sistema representativo de produzir resultados que impliquem a redução da desigualdade e o fim da divisão dos brasileiros em castas separadas pela educação, pela renda, pela cor. (Carvalho, 2002, p. 228-229)

A apatia social, segundo Rosenfield (1994) nasce na padronização da sociedade e dos seus comportamentos, que produz indivíduos voltados somente para a satisfação individual através de bens materiais, alicerçados em uma sociedade do consumo, e que ao final, faz com o os indivíduos fujam das suas responsabilidades coletivas. Há uma indiferença dos indivíduos e de grupos sociais uns em face dos outros e uma legitimação de um Estado situado acima da sociedade e seus cidadãos, decorrente deste processo de uniformização.

Segundo Ferreira Filho (2001), a implantação e efetivação de um regime verdadeiramente democrático, que patrocine a cidadania prospectiva, é missão árdua, delicada e difícil, uma vez que, boa parte do pensamento político sobre a democracia é superficial e até mesmo errôneo. Porém é um regime que permite se reinventar devido ao seu caráter dinâmico e contextual, e cujo entendimento, não deve se esgotar na ideia da tirania da maioria, mas como um regime intrínseco a liberdade de participação política e social, em que possibilita instrumentos para que os governos sejam responsabilizados e que tenham o papel construtivo e compreensivo das necessidades, direitos e deveres humanos universais.

De mais a mais, Kelsen (2000) classifica o povo como uma unidade tão somente no sentido normativo cujas regras obrigatórias estão vinculadas, uma vez que também considera uma ficção atribuir às multiplicidades de indivíduos como um conjunto uniforme. Neste sentido, o povo é apenas objeto do poder sob o qual recai a ordem estatal. Kelsen (2000, p. 37), infere que:

Sob este ponto de vista, os homens entram em campo como sujeitos do poder, somente na medida que participam da criação da ordem estatal. E justamente nessa função, de importância decisiva para a ideia da democracia, porquanto o povo intervém na criação das regras do direito, ocorre a inevitável diferença entre esse "povo" e o povo definido como o conjunto de indivíduos submetidos as normas.

Nesse ínterim, a educação é essencial para compreender e influenciar nas regras do jogo (Bobbio, 1997), bem como acessar as informações transmitidas pelos órgãos públicos, inclusive as disponibilizadas em rede eletrônica, a fim de que não se torne mera reprodução dos aspectos consumistas da sociedade, de acordo com Limberger (2016).

Freire (1967, p. 20) fundamenta: 
Pensávamos numa alfabetização direta e realmente ligada à democratização da cultura, que fosse uma introdução a esta democratização. Numa alfabetização que, por isso mesmo, tivesse no homem, não esse paciente do processo, cuja virtude única é ter mesmo paciência para suportar o abismo entre sua experiência existencial e o conteúdo que lhe oferecem para sua aprendizagem, mas o seu sujeito. (...) Pensávamos numa alfabetização que fosse em si um ato de criação, capaz de desencadear outros atos criadores. Numa alfabetização em que o homem, porque não fosse seu paciente, seu objeto, desenvolvesse a impaciência, a vivacidade, característica dos estados de procura, de invenção e reivindicação.

A matriz da educabilidade do ser humano é a mesma que a esperança, argumenta Freire (2000), pois quando devidamente educado, torna-se crítico e consciente que é um ser inacabado e por isso está sempre em uma incessante busca esperançosa. Ainda mais pelo fato da existência de inúmeras limitações (históricas, econômicas, culturais, etc.), é preciso que a educação esteja embutida pelo discurso esperançoso de quem educa, reafirmando de forma contundente que a mudança da sociedade é possível. A educação precisa formar, e não treinar.

Por meio da educação com ética, a participação não se torna formal, somente de aparência, mas possibilita a participação capaz de influenciar e interagir nas decisões políticas fundamentais, ou seja, a participação real. Evidente que nem todos os interesses de indivíduos e grupo tenderão ao mesmo objetivo ou bem comum, podendo ser conflitantes (Dallari, 1984). Daí que vem a importância da construção de valores democráticos pela sociedade, que, diante dos interesses e concepções divergentes, deverá buscar a conciliação, após a existência de ampla exposição das ideias, possibilidade de esclarecimento e debate para elucidar as questões pertinentes para os cidadãos.

É importante que exista para todos a mesma possibilidade de agir com liberdade para formar e externar opiniões e que ninguém seja impedido de manifestar livremente sua vontade em relação aos assuntos de natureza política. Depois disso, é fundamental que as decisões políticas representem a síntese das diferentes opiniões. Desse modo não haverá risco da ditadura das maiorias e todos terão uma possibilidade real de participação. (Dallari, 1984, p. 92/94)

Deve ser partilhado com a população as decisões públicas para maior participação cidadã, "instituindo de forma democrática e descentralizada os rumos da gestão pública” (Coni \& Dantas, 2017, p. 53), dando efetividade a relação entre democracia e cidadania.

A democracia e a cidadania não podem ser limitadas à eleição, em razão de que, esta é a apenas um dos direitos referente ao exercício da cidadania, não podendo ser limitado nem resumido apenas ao ato de votar nos governantes "sob pena de serem frustrados aspectos de suma importância intrínsecos às garantias dos cidadãos” (Coni \& Dantas, 2017, p. 53). “Como se tem assinalado, participação política não é apenas votar e ser votado” (Dallari, 1984, p. 68), mas adotar práticas e meios hábeis a promover a conscientização, facilitar a informação, e possibilitar decisões reais por parte dos cidadãos.

No mesmo sentido entende Alban (2013, p. 63):

A prática comunicacional é valiosa para a democracia, visto que esta não é construída apenas pelo exercício do direito de sufrágio, mas também pela comunicação entre os cidadãos com o intuito de deliberar e de construir opiniões para a tomada de decisões.

A participação na vida política de um país pelo seu povo é tão importante, que a Declaração Universal dos Direitos Humanos dispõe sobre o assunto em seu artigo 21.

\section{Artigo $21^{\circ}$}

1. Toda a pessoa tem o direito de tomar parte na direção dos negócios, públicos do seu país, quer diretamente, quer por intermédio de representantes livremente escolhidos.

2. Toda a pessoa tem direito de acesso, em condições de igualdade, às funções públicas do seu país. 
3. A vontade do povo é o fundamento da autoridade dos poderes públicos: e deve exprimir-se através de eleições honestas a realizar periodicamente por sufrágio universal e igual, com voto secreto ou segundo processo equivalente que salvaguarde a liberdade de voto.

E o alcance desse direito está consubstanciado pelo fato dos seres humanos serem essencialmente iguais, não justificando a tomada de decisões políticas por alguns poucos para que os outros devam-lhes obediência.

Os tempos modernos, amparados pela forte e extensa tecnologia computacional favoreceram o despertar para uma consciência conjunta e mais ativa. Ademais, a Constituição Federal de 1988 estabelece o voto como cláusula pétrea em seu artigo $60, \S 4^{\circ}$, II, além de reservar ao artigo 14, I, II, III características da democracia semidireta, como já mencionado. É notável que se goza de ampla proteção, no âmbito internacional e interno, dos institutos democráticos e da maior participação popular nas decisões de interesse da sociedade, seja pelo voto, seja pelo maior debate, fiscalização e cobrança do gestor público.

Dallari (1984, p. 33) direciona para a ideia de que "todos os indivíduos têm o dever de participar da vida social, procurando exercer influência sobre as decisões de interesse comum”. Primeiro, por ser um consectário lógico da sociabilidade como inerente condição humana, e em segundo, pelo simples fato de que a falta de uma ampla participação ativa remonta a concentração de poder nas mãos de grupos mais audaciosos e que acabará dominando sem resistência e limitações. Para Dallari (1984) a participação não depende do desejo e do querer dos indivíduos, pois ainda que sedados à participação, estes são utilizados pelos grupos mais ativos, visto que o silêncio é interpretado como sinais de concordância.

Há pessoas que se limitam a se envolver em assuntos de interesse particular se abstendo do debate público, seja por não gostar, seja por não entender, salientando veementemente que assuntos de interesse público é assunto de político. Em acordo, salienta Dallari (1984, p. 34):

Essa atitude revela inconsciência, demonstra grande alienação, pois quem tem os olhos abertos e enxerga a realidade percebe que não existe a possibilidade de fazer completa separação entre os assuntos particulares e os de interesse público. Todo indivíduo exerce alguma influência sobre o meio social em que vive e sofre influência desse meio por mais que procure isolar-se.

Também existem pessoas que movidos por sentimentos egoístas se abstém de participar ativamente, pois já vivem em condições privilegiadas, mesmo com péssimos governos, e não enxergam e nem tem empatia pelas pessoas e famílias que sofrem “a mais injusta discriminação, vivendo na miséria, sem terem o mínimo necessário para viver de acordo com as exigências da dignidade humana" (Dallari, 1984, p. 35).

Os que adotam essa atitude também são inconscientes, pois não percebem que até mesmo a simples manutenção de sua situação econômica privilegiada depende das condições políticas gerais. Além disso, o excesso de exploração e de injustiças cria sempre o risco de uma explosão popular, que, inevitavelmente acarreta graves prejuízos para suas condições de dominadores, seja qual for o resultado final. (...) Existe ainda mais um dever de solidariedade entre seres humanos, pelo simples fato de que ninguém vive sozinho, uns precisam dos outros, bem como porque a degradação de um ser humano representa a degradação de toda a humanidade. (Dallari, 1984, p. 35/36)

Então, é objetivando à construção de uma sociedade livre, justa e solidária (art.1º, I, CF/1988), que se busca uma participação cidadã cujo dever moral dos indivíduos é uma necessidade fundamental da natureza humana, para que seja evitada a imposição de uma ordem injusta e ofensiva à dignidade humana por determinados grupos hegemônicos.

Ainda há, os indivíduos que se exoneram da participação por acharem que não tem força econômica e política suficiente para modificarem a conjuntura social sob a qual se encontram.

Participação democrática ativa, não se traduz tão somente pela participação eleitoral, cujo processo vem sendo aperfeiçoado e tem possibilitado ao povo um espaço para exercer sua vontade. Some-se a participação eleitoral com outras 
formas de participação, em uma visão mais amplificada da cidadania. Dallari (1984), inclusive, aduz outras formas de participação que se destacam e que podem influenciar a via eleitoral, tornando-a menos corruptível e mais idônea e autêntica.

$\mathrm{O}$ cidadão pode participar de forma individual, escolhendo os melhores caminhos, observando a realidade e definido valores, objetivos, modo e lugar de atuação, bem como conscientizando os outros e estimulando a participação. Pode participar também coletivamente através da integração com grupos sociais, uma vez que "a força do grupo compensa a fraqueza do indivíduo" (Dallari, 1984, p.44).

A participação também poderá ocorrer, argumenta Dallari (1984), de forma eventual, quando estiver relacionada a uma situação momentânea, ou de forma organizada, quando pela continuidade se desenvolve uma atividade bem definida e que busca tirar o máximo de proveitos para a coletividade durante maior tempo. Além disso, com amplo trabalho de conscientização, e com a possibilidade de promover a organização de grupos e pessoais que buscam alcançar interesses comuns, "muitas pessoas poderão livrar-se da marginalização e adquirir condições para integrar os processos de decisão política" (Dallari, 1984, p. 54).

Acrescente ainda a participação eleitoral, seja como eleitor, candidato ou militante partidário.

O mínimo a exigir do cidadão em uma democracia moderna, é a participação por meio do voto. O exercício da cidadania não se esgota nele, por óbvio, mas é de extrema importância que seja utilizado de forma consciente para o aperfeiçoamento da democracia. Nesta direção Dallari (1984, p. 55/56):

$\mathrm{O}$ eleitor deve procurar o candidato que mais corresponde ao seu ponto de vista e que esteja mais preparado para exercer as funções para as quais está sendo feito a escolha. A escolha consciente exige do eleitor que procure obter previamente o máximo de informações. De um lado, as informações a respeito da função ou do cargo para o qual está sendo escolhido o representante. (...) De outro lado, é preciso procurar conhecer as características dos que se apresentam como candidatos. O eleitor deverá esforçar-se para saber o máximo possível sobre as atividades que cada candidato já desenvolveu, sobre o preparo de cada um, para exercer as funções em disputa, sobre a coragem cívica do candidato para enfrentar oposições, sobre a firmeza moral de cada candidato para sustentar seus pontos de vista e para resistir ao ataque de corruptores, bem como sobre o espírito público do candidato e sua disposição de fazer sacrifícios pessoais quando isso for exigido pelo interesse dos representados.

De mais a mais, o eleitor necessita saber quais os problemas que rondam a sociedade que se insere, para que possa formar uma opinião quanto as melhores soluções para o aperfeiçoamento social, e qual escolhido seria mais habilitado a solucionar os problemas e mazelas do Estado brasileiro. Dessa forma, o eleitor de acordo com Dallari (1984), deve agir com liberdade, consciência e espirito público, sem nenhuma espécie de barganha, estando ele, atento à sociedade como um todo e das suas respectivas necessidades e exigências.

Do outro lado da moeda, mas em caminho totalmente análogo percorre-se os pressupostos dos candidatos. O candidato deve ter a noção necessária sobre o que pode e deve fazer para melhor representar os interesses do povo, sendo o mandato um compromisso, um encargo e o começo de uma etapa cuja finalidade é satisfazer o interesse público. Dallari (1984, p. 58) argumenta que:

Não é raro que por vaidade, ambição ou inconsciência alguém se apresente como candidato, peça para ser votado, buscando tão-só a obtenção de vantagens pessoais. Nesse caso a pretensão de ser votado já não é mais um modo de participação política, transformando em simples veículo de promoção individual.

Embora haja uma discussão sobre o nível de preparo do candidato e a exigência de ter nível superior para candidatura, ou até mesmo a criação de cursos para candidatos, é pertinente aduzir, consoante Dallari (1984, p. 59) que "o bom preparo intelectual é insuficiente para dar responsabilidade moral, espirito público e sensibilidade política e um indivíduo". 
É prudente, por óbvio, que os candidatos tenham o mínimo de discernimento e conhecimento para compreender as propostas e discussão e do mesmo modo, poder elaborar boas propostas para o interesse público, contudo, tal preparo não necessita ser oriundo de nível universitário, "havendo mesmo, indivíduos que passam por uma Universidade e obtém conhecimentos técnicos especializados sem conseguirem uma visão de conjunto dos problemas sociais" (DALLARI, 1984, p. 59).

Por último, os militantes partidários, são pessoas que estão dispostas a agir dentro da organização dos partidos políticos, democratizando a sua organização e integrando-os as lutas sociais, conforme o exposto por Dallari (1984).

Ao reunir-se, associar-se e movimentar-se em buscas de interesses comuns e importantes, os cidadãos também estão exercendo ativamente seu papel. Não é à toa que a Constituição Federal Brasileira de 1988 expressamente protege o direito de reunião e associação em seu art. $5^{\circ}$, XVI e XVII, respectivamente.

Quanto aos movimentos sociais, cumpre tecer breves considerações. A participação por meio de movimentos organizados, pode ser, em determinadas situações, a melhor forma de mobilização social para o alcance de determinado objetivo, podendo visar "a defesa de situações já conquistadas como pode ser desenvolvido para que certas metas sejam atingidas" (Dallari, 1984, p. 71). Os movimentos podem variar quanto a sua extensão, sejam em relação aos objetivos, sejam em relação ao espaço em que se delimitam ou ao tempo que pretendem alcançar os resultados almejados, o que influenciará diretamente na complexidade do movimento social.

É devido consignar neste artigo, sobre os movimentos sociais que ocorreram no Brasil em junho de 2013 como uma verdadeira força horizontal do povo paulista que foi às ruas, de início, com o objetivo de impugnar o aumento dos preços de transportes públicos em $R \$ 0,20$, e que logo depois expandiu em área e em pleitos, passando a ser uma reivindicação de um conjunto heterogêneo de demandas, diante de boa parte das cidades brasileiras, dispondo Rolnik (2013, p. 5/6):

No decorrer dos protestos, houve uma disputa nos cartazes empunhados pelo conjunto heterogêneo que ocupou as ruas e uma guerra de interpretações das vozes rebeldes. (...) Podemos pensar essa manifestações como um terremoto uma metáfora mais adequada do que o trovão mencionado no editorial do semanário francês -, que perturbou a ordem de um país que parecia viver uma espécie de vertigem benfazeja de prosperidade e paz, e fez emergir não uma, mas uma infinidade de agendas mal resolvidas, contradições e paradoxos. Mas, sobretudo - e isso é o mais importante -, fez renascer entre nós a utopia. No campo imediato da política, o sismo introduziu fissuras na perversa aliança entre o que há de mais atrasado/excludente/prepotente no Brasil e os impulsos de mudança que conduziram o país na luta contra a ditadura e o processo de redemocratização; uma aliança que tem bloqueado o desenvolvimento de um país não apenas próspero, mas cidadão.

As ruas foram palcos de indignação, revolta e protesto, que não é nenhuma novidade histórica. Porém, a novidade encontra-se na utilização da internet por meio das redes sociais, para a organização do movimento e o debate político. Rolnik (Cidades Rebeldes, 2013) assevera que, ainda que o monopólio da formação da opinião pública esteja sobre o domínio da grande mídia, com produção de temas extremamente enviesados, a internet foi de fundamental importância para combinar o protesto, informar e reunir adeptos. Não foi pela grande mídia que o movimento tomou proporções nacionais, mas, pela dialeticidade mediada pelas novas mídias sociais.

Secco (Cidades Rebeldes, 2013, p. 66) informa que:

Segundo a Folha de S. Paulo, 84\% dos manifestantes paulistas no dia 17 de junho não tinham preferência partidária, $71 \%$ participavam pela primeira vez de um protesto e $53 \%$ tinham menos de 25 anos. Pessoas com ensino superior eram 77\%. Alguns números revelam o óbvio: desde não havia protestos amplos e generalizados no país, logo, só poderia ser a primeira vez dos jovens manifestantes. Além disso, a preferência partidária sempre foi baixa no Brasil, embora tenha se revelado ainda menor na pesquisa citada. Nas manifestações de 20 e 22 de junho em São Paulo, a pauta das ruas se duplicou. De um lado, a pauta popular, organizada de baixo para cima nos primeiros dias, na qual era central a questão da tarifa de transporte, induzida pelo Movimento Passe Livre (MPL). De outro, uma pauta que veio de cima para baixo. Esta era a pauta de massa. A questão aqui não é o conteúdo, mas a forma, ou seja, o que 
importa é como a "vanguarda" interpela os demais. A linguagem de cima é apelativa como a publicidade. A de baixo assemelha-se ao jogral, escolhido pelo MPL em contraposição ao tradicional uso de carros de som e palanques.

Ainda, declara Secco (2013) que os manifestantes virtuais se reduzem a criticar os políticos, mas não a forma que é feita a política, e que, os temas produzidos pela internet não passam de uma produção continuada dos monopolistas da comunicação, pois "a internet é também um espaço de interação entre indivíduos mediada pelo mercado de consumo e vigiada pela “inteligência” dos governos" (Secco, 2013, p. 67).

Salutar relembrar que a internet não pode ser um meio para perpetuação de domínio e tirania de governos pseudodemocráticos, como bem criticou Bobbio (1997, p. 30/31):

Inútil dizer que o controle público do poder é ainda mais necessário numa época como a nossa, na qual aumentaram enormemente e são praticamente ilimitados os instrumentos técnicos de que dispõem os detentores do poder para conhecer capilarmente tudo o que fazem os cidadãos. Se manifestei alguma dúvida de que a computadorcracia possa vir a beneficiar a democracia governada, não tenho dúvida nenhuma sobre os serviços que pode prestar à democracia governante. $\mathrm{O}$ ideal do poderoso sempre foi o de ver cada gesto e escutar cada palavra dos que estão a ele submetidos (se possível sem ser visto nem ouvido): hoje este ideal é inalcançável. (...) "Quem controla os controladores?" Se não conseguir encontrar uma resposta adequada para esta pergunta, a democracia, como advento do governo visível, está perdida.

Limberger (2016) informa que os países escandinavos possuem o menor índice de corrupção do mundo, pelo simples fato da disponibilização de assuntos de interesse público na internet para que os cidadãos possam acessar e consultar, concluindo que a ampliação da transparência através da internet diminui drasticamente a corrupção, assim como, ajuda na concretização dos direitos sociais.

Conforme a pesquisa realizada pelo site Transparência Internacional Brasil, o Índice de Percepção da Corrupção (IPC) 2020, que mede níveis de percepção de corrupção no setor público em todo mundo, detectou que o Brasil permanece estagnado em patamar muito ruim, abaixo da média dos BRICS (39), da média regional para a América Latina e o Caribe (41) e mundial (43) e ainda mais distante da média dos países do G20 (54) e da OCDE (64).

A variação de 35 pontos, em 2019, para 38 pontos, em 2020, está dentro da margem de erro da pesquisa (4,1 pontos para mais ou para menos). O aumento fez o país passar da $106^{\mathrm{a}}$ posição para a $94^{\mathrm{a}}$, num ranking de 180 países e territórios, ainda atrás de países como Colômbia, Turquia e China. A Transparência Internacional alerta que o país enfrenta sérios retrocessos no combate à corrupção, denunciados no relatório Brazil: Setbacks in the Legal and Institutional Anti-Corruption Frameworks. O IPC usa uma escala de zero (altamente corrupto) a 100 (altamente íntegro), avaliando um total de 180 países.

A luta contra a corrupção, que foi bandeira de boa parte da classe política eleita nos últimos anos, não se transformou em medidas concretas de enfrentamento do problema. Nenhuma agenda efetiva de reformas anticorrupção foi apoiada pelo governo e aprovada pelo Congresso. Pelo contrário, ocorreram graves retrocessos institucionais, principalmente com a perda de independência de órgãos fundamentais como a Procuradoria-Geral da República e a Polícia Federal.

Além disso, o avanço do autoritarismo, com ataques crescentes aos jornalistas e à sociedade civil, ameaça outra frente essencial para a luta contra a corrupção: a produção de informação de interesse público e o controle social.

Em 2020, com a pandemia do coronavírus, as atenções se voltaram para o enfrentamento da crise sem precedentes. Com a necessidade real de responder urgentemente às necessidades da sociedade, os riscos de corrupção também aumentaram. No mundo inteiro, foram inúmeros os casos de corrupção, que mostraram suas consequências mais perversas em meio à terrível crise humanitária. Em nosso país, a falta de integridade de nossos governantes literalmente tirou o oxigênio das pessoas.

Toda grande crise acelera a história. Mas para qual direção? Estamos em uma encruzilhada histórica em que podemos agravar injustiças estruturais ou aproveitar este momento de grandes transformações para atacar os problemas pela raiz. Agora, mais do que nunca, será necessário que as grandes decisões sejam tomadas com transparência, com integridade e em nome do bem comum. 
Não será através de soluções populistas e autoritárias que construiremos um país íntegro e justo. Será através do fortalecimento da nossa democracia e de uma cidadania consciente, unida, livre e ativa na luta por seus direitos. (IPC, 2020)

No Brasil, a Transparência Internacional se uniu as Escolas de Direito do Rio e de São Paulo da FGV para promover medidas combativas à corrupção com base nas experiências e resultados internacional, criando-se a plataforma Wikilegis, a qual os cidadãos podem se cadastrar para conhecer, comentar e sugerir modificações aos projetos de lei, propostas de emenda constitucional e resoluções que pretendem oferecer uma resposta sistêmica à corrupção no Brasil. Embora seja uma plataforma recente, mostra o avanço para as relações democráticas brasileiras e permitindo uma participação do cidadão através do espaço em rede. Claro, que, não basta a participação se não houver uma agenda legislativa e executiva apta a escutar e atender o cidadão.

A noção dos antigos sobre res publica segundo Limberger (2016) traz o significado que a esfera pública deve tornar seus atos públicos, sendo importante o cidadão se informar para poder exercer um papel importante na sociedade e formar sua opinião, incorrendo no cumprimento do princípio democrático.

A relevância que se dar para opinião pública está intrinsecamente ligada a quantidade ofertada à população de "visibilidade, cognoscibilidade, acessibilidade e, portanto, controlabilidade dos atos de quem detém o supremo poder" (Bobbio, 1997, p. 89).

O Estado Democrático de Direito tem como princípio basilar, a publicidade, e inerentemente o direito à informação. Isto porque ambas são de extrema importância para a participação cidadã.

A revolução tecnológica visa a propiciar uma administração mais eficiente e eficaz, mais próxima ao cidadão, mais moderna, mais rápida, que permita oferecer ao cidadão um serviço muito melhor. Exige-se uma administração mais transparente, democrática, mais controlada, mais acessível, mais respeitosa com a privacidade. (Piñar Mañas, 2011, p. 30 apud Limberger, 2016, p. 47)

A tecnologia digital tem extremo potencial para aperfeiçoamento da democracia através do desenvolvimento comunicacional entre os cidadãos por meio de criação de foros públicos em rede, que ao acessarem os dados disponibilizados pela administração pública, poderão exercer o controle diretamente e/ou indiretamente, influir nas deliberações e tomadas de decisões.

Complementando esta ideia de legitimidade e respeito as regras para a credibilidade das instituições e gestores pela sociedade, Coni e Dantas (2017, p. 18) afirmam que:

Em verdade, a boa governança demanda um aparato legislativo para que os atores sociais possam atuar com segurança, cientes dos limites, das regras permissivas e autorizações legais, evitando condutas marginais da sociedade e/ou eivada de ilicitudes. De igual forma, é preciso que este aparato legal encontre respaldo cultural e social, eis que de nada adiantaria a adoção de modernos sistemas de governança, sem que houvesse compatibilidade e aceitação social, de modo que fosse respeitado e adequado à realidade cultural onde está sendo implantado. Faz-se ainda premente que haja coerente aparato institucional, que legitime e prestigie os regramentos em torno da governança, fazendo-os valer na prática, efetivando os ditames abstratamente estabelecidos, de modo que haja plena confiança e segurança jurídica de que tais procedimentos serão respeitados e cumpridos.

Cumpre salientar que, embora existam sites, do ponto de vista local, e também nacional (Governo Digital e Participa, por exemplo), e diversos portais, de publicidade e informações de dados público, não é suficiente para o pleno exercício da cidadania se não houver estímulos e habilidades por parte dos usuários. Conforme Marques (2016) se deve evitar a aparência de progresso, quando na verdade tem-se verdadeira exclusão digital, inferindo que: 
Não basta os dispositivos midiáticos estarem tecnicamente disponíveis se a difusão e a utilização deles forem restritas a poucos e pequenos grupos. Sem um planejamento diligente de políticas voltadas a garantir a inclusão dos cidadãos, as próprias experiências de e-governo ou e-participação, aplaudidas em um primeiro momento, podem acabar atuando como elementos de segregação e, consequentemente, ter seus efeitos limitados. Simples existência de soluções tecnológicas insiste-se, não é condição suficiente para resolver problemas de origem política ou social (Marques, 2016, p. 35).

Assim, não basta que os gestores disponibilizem as informações, ainda que corretas e idôneas, de interesse público, se estas não forem passiveis de inclusão. E inclusão se faz quando há uma oferta de equipamentos e eficiente conectividade que possibilitem a comunicação e interação em rede, e também quando há uma receptividade, entendimento e ampla cognição do cidadão acerca dos dados transmitidos via internet, sendo pré-requisito para uma devida compreensão e conscientização, uma educação de qualidade e respaldada em valores humanos e éticos. Fundamenta Santaella (2003, p. 70/71):

As consequências dessas tecnologias para a comunicação e a cultura são remarcáveis. Estamos, sem dúvida, entrando numa revolução da informação e da comunicação sem precedentes que vem sendo chamada de revolução digital. (...) Aliada a telecomunicação, a informática permite que esses dados cruzem os oceanos, continentes, hemisférios, conectando potencialmente qualquer ser humano do globo numa mesma rede gigantesca de transmissão e acesso que vem sendo chamada de ciberespaço. Catalisados pela multimídia e hipermídia, computadores e redes de comunicação, passam assim por uma revolução acelerada no seio da qual a internet, rede mundial das redes interconectadas, explodiu de maneira espontânea, caótica, superabundante.

Conforme Maior (2013), as mobilizações que ocorreram no Brasil, mesmo com toda a heterogeneidade, foram bem claras na convergência dos anseios da população brasileira, quais sejam, mais serviços públicos e de qualidade, um Estado social mais atuante e pautado pelo imperativo de uma ordem jurídica que seja apta a resolver a nossa grave e histórica questão social, a desigualdade social.

O que para alguns parece globalização, para outros significa localização; o que para alguns é sinalização de liberdade, para muitos outros é um destino indesejado e cruel. A mobilidade galga ao mais alto nível dentre os valores cobiçados - e a liberdade de movimentos, uma mercadoria sempre escassa e distribuída de forma desigual, logo se torna o principal fator estratificador de nossos tardios tempos modernos ou pós-modernos. (BAUMAN, 1999, p. 7)

Neste ínterim, Coni e Dantas (2017, p. 46) estabelecem que "espalha-se no ar os protestos exercidos local e globalmente, por vários povos, de composição plural, mediante a liberdade de reunião, em defesa de outros direitos”, e, que, embora existam especificidades culturais e territoriais, estes protestos convergem em sua finalidade e sentido. Buscam a garantia e efetividade dos direitos humanos e fundamentais, pautados pelo ideário de liberdade e pelos direitos que possibilitam a sociedade de informação, a exemplo do direito à reunião digital. $\mathrm{O}$ exercício dos direitos fundamentais de reunião, expressão e informação, torna possível a reivindicação pela garantia e efetivação de outros direitos essenciais para a existência digna humana.

Os protestos se dirigem a diversos e distintos direitos, mas todos eles concernem, basicamente, à desmercantilização de condições existenciais que permita a plena realização da pessoa humana, além de exprimirem a participação cívica no processo democrático ou na sua construção e afirmação. Os vários povos exercendo um direito, afirmando a cidadania - mesmo onde lhes é negada -, para clamar, política e juridicamente, por outros direitos, quer para assegurá-los, quer efetivá-los. (Coni \& Dantas, 2017, p. 47)

São movidas por um sentimento de revolta e têm por finalidade resgatar a dignidade humana que fora violentada por ação ou omissão do próprio Estado ou entes ligados ao poder econômico privado" (Maior, 2013, p. 79). Dessa maneira, é inconcebível a deslegitimação dos movimentos sociais através de ações repressivas pela força policial, ataque midiático e fórmulas jurídicas, tal como entendia o ex-presidente Washington Luís na década de 1920, que a questão social era uma 
“questão de polícia” (Carvalho, 2002, p. 63), e que ainda integra a mentalidade brasileira. Infere-se por Maior (2013, p. 80/83) que:

Há de se lembrar que vivenciamos uma sociedade de classes, típica do modelo capitalista, e mudanças sociais concretas, no sentido da diminuição da desigualdade e da construção de um Estado efetivamente voltado à questão social, somente ocorrerão se for evidenciado o conflito entre o trabalho e o capital, de modo a corrigir várias distorções dos meios de produção e do modo de exploração do trabalho, que, na nossa realidade, têm alimentado a lógica da má distribuição da renda produzida, gerando segregação e precarização, além do grave descompromisso com as repercussões públicas e sociais do processo de produção.(...) Como já advertira Octavio Ianni, no Brasil, “em geral, os setores sociais dominantes revelam uma séria dificuldade para se posicionar em face das reivindicações econômicas, políticas e culturais dos grupos e classes subalternos. Muitas vezes reagem de forma extremamente intolerante, tanto em termo de repressão como de explicação. Essa inclinação é muito forte no presente, mas já se manifestava nítida no passado”. (...) O que vivemos no Brasil há anos, como é fácil perceber para quem ler a Constituição de forma não preconceituosa e olhar à sua volta, é uma resistência ao cumprimento da ordem jurídica constitucional, pautada pelos direitos humanos e pelos preceitos do direito social. E o pior é o fato de que todos aqueles que tentaram demonstrar isso publicamente até o passado recente foram criminalizados ou discriminados de alguma forma, tornando assim, até agora, irrealizável o projeto da construção de uma sociedade verdadeiramente justa.

Ainda, segundo Maior (2013), os movimentos sociais mobilizados através de atos políticos e na luta por direitos, não estão destoando do ordenamento pátrio, pelo contrário, as reivindicações agem amparadas pela própria Constituição Federal a qual, fora instituída a partir dos valores do Estado Democrático de Direito. Inclusive, as revoltas estão lastreadas pelo sentimento de que "determinadas leis, sobretudo quando mal interpretadas e aplicadas, têm estado, historicamente, a serviço da criação e da manutenção da intensa desigualdade que existe em nosso país” (Maior, 2013, p. 80).

A parcela que vai às ruas manifestar-se, luta por melhores condições de vida causados pelos desajustes econômicos, políticos e culturais, e contra toda a estrutura que inviabiliza a satisfação de tais interesses, não podendo a lei ser usada como instrumento de impedimento da revolta popular.

Há uma expectativa acerca da Internet para a promoção da democracia. Por meio dela, o acesso à informação política seria facilitado permitindo que os cidadãos tivessem a aquisição do mesmo conteúdo de seus líderes, passando o povo realizar de forma efetiva o seu direito soberano, fiscalizando os representantes, solicitando informações das autoridades e órgão competentes, expressando suas opiniões de forma livre e igualitária, e exigindo respostas e soluções dos governos para os problemas sociais, econômicos e políticos. Conforme Castells (2003), a interatividade permite que os registros públicos e as informações de caráter não sigiloso, possam ser disponibilizados online.

Assume Castells (2016) que os movimentos sociais ao longo da história foram e ainda são as legitimas alavancas de mudanças sociais. Aduz que são originários de crises que tornam a vida dos indivíduos insuportável, e insustentável a existência cotidiana para uma elevada quantidade de pessoas. Além disto, some ao fato da degradação das condições materiais de vida, a extensa crise de legitimidade dos governantes, como mola propulsora dos movimentos sociais para mudar governantes ou as regras que moldam suas vidas.

A mudança social envolve uma ação individual e/ou coletiva que é emocionalmente motivada, pela indignação em face das injustiças e pela esperança por mudanças, que, segundo Castells (2016) ganham forças por meio de inspirações de revoltas exitosas transmitidas a todo o globo pela internet. É lastreado pela experiência histórica e na observação de movimentos sociais que Castells (2016, p. 161/162) conclui que "muitas vezes são desencadeados por emoções derivadas de algum evento significativo que ajuda os manifestantes a superar o medo e desafiar os poderes constituídos apesar do perigo inerentes suas ações".

Caracterizado o constitucionalismo "enquanto movimento de luta pela defesa dos direitos fundamentais e pela limitação do exercício do poder" (Coni \& Dantas, 2017, p. 51), salienta-se que esse possui diversos aspectos característicos da 
complexidade da sociedade contemporânea informacional, resultando em uma ressignificação do Estado Democrático de Direito.

Coibir a expressão popular e suas inúmeras demandas, é coibir o princípio fundamental da República (art. $1^{\circ}$, II), ou seja, é inibir, mitigar e marginalizar o direito de exercer a cidadania para a manutenção e aperfeiçoamento do Estado Democrático de Direito, que possui uma Constituição que regida pelos princípios da prevalência dos direitos humanos (art. $4^{\circ}$ II) e que prevê como objetivos fundamentais da República Federativa do Brasil, e segundo Maior (2013, p. 80/81):

i) construir uma sociedade livre, justa e solidária; ii) garantir desenvolvimento nacional; iii) erradicar a pobreza e a marginalização e reduzir as desigualdades sociais e regionais; iv) promover o bem de todos sem preconceitos de origem, raça, sexo, cor, idade ou quaisquer outras formas de discriminação.

Impugna Maior (2013) que os conflitos sociais são decorrentes de um reiterado descumprimento e um conjunto cruel de ilegalidades cometidas pelos poderes públicos ao ignorarem a efetividade das normas constitucionais, e a situação social insuportável para boa parte dos brasileiros.

Assim, o direito social depende da vivência concreta da democracia política para que as pessoas excluídas do sistema econômico ou incluídas numa lógica de exploração possam se organizar para questionar criticamente a realidade, expondo publicamente os seus problemas e reivindicando as soluções necessárias. É assim, por conseguinte, que os sociais são acolhidos pelo direito de forma a tornar juridicamente válida $-\mathrm{e}$, portanto, legítima - a sua manifestação e o seu inconformismo diante da injustiça identificada, sendo, portanto, a "criminalização" dos movimentos sociais apenas um método do já superado direito liberal. (Maior, 2013, p. 82)

Só permitindo que a democracia seja realmente exercida, inclusive por meio da organização de diversos grupos sociais, em ações concretas, é que as reivindicações poderão ser direcionadas e conduzidas à vontade popular de modo lúcido e claro, bem como dar voz às indignações contra a agressividade dos que comandam as regras do jogo democrático e que desrespeitam as novas constitucionais.

A internet é um meio fundamental e hábil a patrocinar o exercício da verdadeira cidadania, de participação, opinião, liberdade e respeito, se bem direcionada a este intuito, se tornando um verdadeiro ciberespaço para o debate público e para as práticas da democracia contemporânea, que é de extrema complexidade, e mescla características da democracia direta e da democracia representativa, para satisfazer as expectativas de uma sociedade pós-moderna, globalizada e digital, já informando Bobbio (1997, p. 52) que:

De fato, democracia representativa e democracia direta não são dois sistemas alternativos (no sentido de que onde existe uma não pode existir a outra), mas são dois sistemas que se podem integrar reciprocamente. Com uma fórmula sintética, pode-se dizer que num sistema de democracia integral as duas formas de democracia são ambas necessárias mas não são, consideradas em si mesmas, suficientes.

Conclui-se, desse modo, que os movimentos sociais políticos são protegidos juridicamente e assegurados em sua atuação, dada a importância para a transformação social, e superação das injustiças e consequente dignidade do indivíduo, sem a qual não seria possível a sobrevivência. O Estado, na figura dos seus gestores deverão ouvir a voz que ecoa das redes virtuais e físicas, e promovendo ações institucionais que efetivem políticas públicas adequadas a sanar as necessidades dos brasileiros.

A ordem jurídica está posta no sentido de coibir a intolerância e reafirmar o compromisso, assumido internacionalmente, de respeito aos direitos humanos de índole social, reconhecendo, sobretudo, como fundamentais os direitos de liberdade de expressão e de reivindicação dos excluídos (sem-teto, sem-terra e desempregados), dos trabalhadores, dos estudantes e das minorias e discriminados (mulheres, homossexuais, negros, índios, pessoas com deficiência), constituindo-se ainda em relevante instrumento para coibir todas as práticas repressivas, antissociais, antissindicais, antidemocráticas e preconceituosas. Esse é o presente que irrompeu nas ruas: a seriedade quanto à 
efetividade dos preceitos jurídicos do direito social. Cumpre às estruturas de poder, enfim, levar adiante esse projeto, o que é, ademais, a sua função (Maior,2013, p. 84).

Como argumentado em Coni e Dantas (2017), os cidadãos brasileiros já estão fartos dos desvarios e da ineficiência estatal, bem como, cada vez mais intolerantes com os desvios decorrentes da corrupção institucionalizada e endêmica, e que mitigam a cidadania, clamando por ampla participação e poder de influência nas políticas públicas. Somente com abundância de participação, o povo pode avaliar, opinar e modificar a gestão estatal ineficiente, sem controle e monitoramento, no que tange à tutela dos direitos fundamentais dos cidadãos.

Impende reafirmar que a cidadania ativa para se realizar necessita da educação capaz de modificar o sujeito instrumentalizando-o, conscientizando-o, e preparando-o para uma vida coletiva, de respeito mútuo e responsabilidade ética. Além disso, necessita de ampla informação respaldada na transparência e publicidade, e também, de estímulo à participação na vida pública como próprio alicerce para garantir que os direitos fundamentais constitucionais sejam concretizados, diante de uma sociedade pós-moderna de valores mercadológicos e coisificação humana.

Frise-se, que as tecnologias de informação e comunicação são um meio hábil a potencializar esta cidadania ativa, principalmente no ciberespaço, que funciona como espaço sem barreiras físicas de deliberação, devendo ser amadurecido para que em um futuro não muito distante possa servir pró-civicamente para o desenvolvimento e aperfeiçoamento de uma democracia verdadeiramente participativa.

\section{Considerações Finais}

No desenvolvimento dessa pesquisa, compreendi que cada vez mais é preciso tratar de assuntos que remontam a maior participação dos cidadãos brasileiros para deliberarem por seus interesses os quais, historicamente ficaram restritos a indivíduos tirânicos ou grupos de poder. Destrinchou-se a temática de modo que não fosse esgotado o assunto, mas que possibilitasse os questionamentos acerca do processo de implantação de uma cultura constitucional e a possibilidade de uma capacitação da cidadania brasileira voltada para a satisfação dos valores humanos.

Nesse sentido, a complexidade social oriunda dos tempos modernos necessita de novas formas de regimes políticos para se organizarem que visem a cidadania integral e os anseios iluministas, tendo-se como base a efetivação principiologia das constituições modernas, as quais tiveram como marco histórico na Europa continental, o pós-guerra, e especificadamente no Brasil, a Constituição de 1988 e o processo de redemocratização que ela ajudou a protagonizar (Barroso, 2017).

Coube compreender a deficiência participativa dos brasileiros nos processos decisórios, suas bases históricas e a ausência de uma percepção valorativa que busque a dignidade humana indiscriminadamente como a matriz para uma sociedade que almeja a fraternidade, justiça social, liberdade e felicidade. Ainda, apresentei a possibilidade de se implantar uma mentalidade cidadã a partir do início do ensino formal, trazendo algumas propostas legislativas que tiveram como objetivo implantar o ensino da constituição federal a partir da educação básica. Embora os projetos a nível nacional encontrem-se parados, de forma atômica, alguns Municípios têm adotado a ideia (Constituição em miúdos, por exemplo), e que a longo prazo poderemos inferir os resultados.

A respeito, infere Barroso (2017) que uma Constituição não é só técnica, precisando colacionar a capacidade de simbolizar conquistas e de mobilizar o imaginário das pessoas para novos avanços. Assim, além de um surgimento de sentimento constitucional tímido, é necessário que os brasileiros compreendam, de fato, os valores que estão incutidos nela. Os valores sociais devem estar suficientemente enraizados no ideário popular para que vislumbrem a Constituição de 1988 com a devida carga emancipatória que ela contém. De forma análoga, fundamentou-se a importância da liderança responsável com os ideais e instrumentos do Estado Democrático de Direito para alcance das demandas públicas. 
Ainda, com a massificação da comunicação, é preciso desvincular a opinião pública dos instintos primitivos, colhendo-se na razão a verdadeira interpretação dos fatos, e se afastando da vontade fabricada, manipulada e artificial. Em uma democracia não deve haver necessariamente uniformidade de opiniões, mas, a possibilidade de consenso e dissenso mediante a ampla informação e debate, com o mínimo de convergência de valores (para Dahl, 2001, se as subculturas forem extremamente opostas e conflitantes, incapazes de obter através de ações conciliatórias, uma solução, seria impossível que instituições democráticas se desenvolvesse e resistisse).

Dessa forma, os valores inerentes a uma sociedade pós-moderna e democrática devem ser incutidos nos corações do homem, e isso é possível por meio de um processo ativo e crítico de educação, que eduque o brasileiro para a cidadania humanizada. A democracia é o poder visível cada vez mais buscado pelos povos.

Nesse contexto a ONU, cada vez mais preocupada com os direitos humanos frente a um modelo capitalista excludente, tem buscado interceder nas constituições dos Estados com o objetivo de possibilitar uma maior democratização de suas instituições através de uma constituição principiológica, em que o ser humano é a causa primeira. Além disso, há uma proteção internacional da internet, por entender que este meio tecnológico é de extrema importância para prevalência dos direitos humanos e fundamentais, e uma ferramenta ímpar para a socialização.

A sociedade informacional do século XXI busca nas novas tecnologias de informação e comunicação, a forma adequada à satisfação dos seus anseios. Por ser um espaço livre, descentralizado e fluído, é possível que os indivíduos se organizem conforme grupos de interesse para fazer ecoar a voz até então cessada. A internet é uma poderosa ferramenta de debate, fiscalização, informação e reivindicação, dada a sua falta de limites de tempo e espaço.

Reconhece, em Castells (2016), que a expansão comunicacional de forma ilimitada por meio do ciberespaço possibilitou os movimentos sociais do novo século, os quais foram embutidos de indignação, quanto ao sistema existente de dominação e massacre das necessidades humanas, e de esperança, quanto a possibilidade de alterar estas características para uma sociedade mais altruísta e ética.

Contextualizando com a realidade brasileira, percebe-se que os movimentos nacionais tiraram da zona de conforto uma sociedade que ainda tem um déficit de cidadania consciente e ativa. A infinita indignação quanto aos governantes, a má gestão dos serviços públicos, a corrupção institucionalizada, os privilégios das elites financeiras que comandam o país, a falta de garantias suficientes para os brasileiros viverem dignamente, entre inúmeras outras reivindicações, ainda que pulverizadas, são pautas recorrentes de diversas vertentes sociais.

No entanto, ainda há um longo caminho para o desenvolvimento e aperfeiçoamento da desestabilizada democracia brasileira. Ao trazer para a reflexão o histórico nacional de desigualdade e exclusão, tornou-se possível olhar com empatia para a deficitária cidadania brasileira atual, sem contudo, justificar a sua manutenção, mas propor antídotos para um futuro diferente.

Ao se ter consciência da precariedade cidadã e os motivos que assim fizeram, é possível concluir que a cidadania brasileira só poderá ser impulsionada se houver educação voltada para uma perspectiva constitucional e informação transparente disponibilizada pelos órgãos e agentes públicos.

Não se trata da educação estritamente técnica, de desenvolvimento das faculdades mercadológicas, mas uma educação ética e libertadora que possibilite mudança de postura dos cidadãos brasileiros e permita o surgimento de uma cultura democrática. A educação evita que sujeito seja enganado, ludibriado e fique desatento diante do interesse público. A educação adequada alimenta as esperanças e fomenta a mudança individual e social. O indivíduo educado ele é autônomo, livre e consciente, e por isso pode debater, fiscalizar, votar e se manifestar adequadamente.

A educação anda de mãos dadas com a informação, um não é suficiente sem o outro para aperfeiçoar e desenvolver a democracia nacional. Além da educação que modifique as posturas negativamente enraizadas do cidadão brasileiro, é preciso 
também que seja acessível e disponibilizado os dados e informações da gestão nacional para que possa aumentar o controle pela população.

Não há dúvidas que o grande problema brasileiro é a inadequada gestão e planejamento dos recursos públicos, muitas vezes desviados pela corrupção sistêmica do país e alicerçados a interesses egoísticos de determinados grupos que em nada querem contribuir para a emancipação brasileira.

Este ambiente de total ineficiência política tem causado grave crise de representatividade, uma vez que os brasileiros estão cada vez mais indignados com o rumo da política no país. Porém, da mesma forma que se indignam, se exoneram de qualquer responsabilidade no que tange as causas coletivas, e isso resulta em uma democracia de baixa intensidade e em uma cidadania deficiente.

Ao não se sentirem diretamente responsáveis pelos rumos da sociedade, se acomodam e não participam da vida política. As formas e possibilidades de participação na vida do País são inúmeras, porém, é preciso que se tenha a cognição para compreender as necessidades nacionais, os objetivos da república e os princípios constitucionais. Reconhece-se, que os cidadãos são diuturnamente desprestigiados e massa de manobra de grupos de interesse, o que ocasiona extrema obstacularizacão na efetivação da Constituição de 1988.

Assim, por meio da educação democrática e ética conjuntamente com maior instrumento de informação e controle pela sociedade, é possível tornar a democracia mais efetiva e transparente. Os países considerados com democracia plena têm nesses recursos a base de suas sociedades (The Economist Intelligence Unit, 2018).

Ratifique-se que a internet é uma ferramenta fundamental a possibilitar e ampliar a participação cidadã, na medida em que tem um poder comunicacional descentralizado e ilimitado, permitindo que os cidadãos dialoguem e possam se reunir, bem como tenham acesso às notícias, informações e dados não ofertados pela grande mídia.

Conclui-se, que a cidadania ao ser devidamente impulsionada por meio da educação prospectiva, em conjunto com a boa governança, potencializada pela hiperconectividade do século XXI, é capaz de promover não somente uma democracia de qualidade, mas também, efetivar as garantias fundamentais, uma vez que os cidadãos podem, através das manifestações e do controle, conquistar seus direitos inerentes à sua dignidade, bem como compreendê-los, e assim, poder viver em uma sociedade justa, livre e igualitária.

Diante disso, esta pesquisa pretendeu compreender a cidadania brasileira e analisá-la, direcionando-a para a satisfação da dignidade humana no processo de concretude dos princípios constitucionais da Lei Maior do País.

No entanto, compreendo que, dada a natureza e complexidade, o assunto não se esgota neste artigo, pois há um grande leque para pesquisadores inquietos desenvolverem a temática, diante da crescente pulverização das relações sociais no Brasil, da relativização de valores caros à sociedade, da defasagem da educação cidadã e do desvirtuamento dos anseios do constituinte. Assim, este estudo almeja despertar o interesse de diferentes pesquisadores, para que novas investigações sejam realizadas no âmbito das ciências humanas, dentre elas, o Direito, a Ciência Política e a Educação, haja vista pouca produção nacional nesse sentido, tendo como meta identificar e desenvolver a temática acerca da cidadania brasileira e deficiência/ausência de uma cultura constitucional, apontando caminhos para a superação dos problemas encontrados, inclusive propondo uma discussão científica acerca do ensino do Direito Constitucional a partir da idade escolar e o desenvolvimento do País.

\section{Referências}

Alban, T. (2012). Democracia e esfera pública no ciberespaço, Salvador. Assembleia Legislativa do Estado da Bahia, 2012.

Barroso, L. R. (2001) Fundamentos teóricos e filosóficos do novo direito constitucional brasileiro (Pós-modernidade, teoria crítica e pós-positivismo). $34 \mathrm{f}$. Artigo. Professor Titular de Direito Constitucional da UERJ. Mestre em Direito pela Yale Law School. Advogado no Rio de Janeiro. 
Research, Society and Development, v. 10, n. 7, e35810716789, 2021

(CC BY 4.0) | ISSN 2525-3409 | DOI: http://dx.doi.org/10.33448/rsd-v10i7.16789

Barroso, L. R. (2017). Neoconstitucionalismo e constitucionalização do direito ( $O$ triunfo tardio do direito constitucional no Brasil) .https://luisrobertobarroso.com.br/wpcontent/uploads/2017/09/neoconstitucionalismo_e_constitucionalizacao_do_direito_pt.pdf.

Bauman, Z. (1999). Globalização: as consequências humanas. Jorge Zahar.

Benevides, M. V. de M. (1991). A cidadania ativa: Referendo, plesbicito e iniciativa popular. Editora Ática, 1991.

Boaventura, E. M. (2004). Metodologia da pesquisa: monografia, dissertação e tese. Editora Atlas.

Bobbio, N. (1997). O futuro da democracia (uma defesa das regras do jogo). Trad. Marco Aurélio Nogueira. Paz e Terra.

Bonavides, P. (2012). Ciência Política. (19a ed.) Editora Malheiros.

Brasil. Constituição (1988). Constituição da República Federativa do Brasil. Senado Federal: Centro Gráfico, 1988.

Brasil, Constituição em miúdos. https://www2.senado.leg.br/bdsf/bitstream/handle/id/514442/001045274_Constituicao_em_miudos.pdf?sequence.

Brasil, Lei No 9.394, De 20 De Dezembro De 1996. Estabelece as diretrizes e bases da educação nacional. Diário Oficial da República Federativa do Brasil, Brasília, DF. http://www.planalto.gov.br/ccivil_03/leis/19394.htm.

Brasil, Projeto De Lei 403/2015. Torna-se obrigatória a inclusão no Currículo Oficial de Ensino fundamental e médio as disciplinas Direito Administrativo, Direito Constitucional e Direito do Consumidor. Câmara dos Deputados, Brasília, https://www.camara.leg.br/proposicoesWeb/fichadetramitacao?idProposicao=947708.

Brasil, Projeto De Lei N 70 DE 2015. Altera a Lei de Diretrizes e Bases da Educação Nacional para inserir novas disciplinas obrigatórias nos currículos dos ensinos fundamental e médio. Senado Federal, Brasília, DF. https://www25.senado.leg.br/web/atividade/materias/-/materia/119869.

Brasil, Projeto De Lei No 38 DE 2015. Acrescenta o inciso V ao art. 36 da Lei no 9.394, de 20 de dezembro de 1996, Lei de Diretrizes e Bases da Educação, para incluir "Cidadania" como disciplina obrigatória no currículo do ensino médio do Brasil e dá outras providências. Senado Federal, Brasília, DF. https://www25.senado.leg.br/web/atividade/materias/-/materia/119721.

Brasília, DF, Senado Federal, 2017. https://www12.senado.leg.br/radio/1/noticia/2017/03/27/municipio-de-minas-gerais-aprova-inclusao-do-ensino-daconstituicao-na-grade-curricular-do-ensino-fundamental.

Cabral. A. M. (2006). Ética, responsabilidade e democracia. http://www.achegas.net/numero/34/cabral_34.pdf.

Carvalho, J. M. de. (2002). Cidadania no Brasil: O longo Caminho. (3a ed.), Civilização Brasileira.

Castells, M. (2016). A era da informação: economia, sociedade e cultura: Volume I-A sociedade em rede. (17a ed.), Editora Paz e Terra

Castells, M. (2003). A galáxia da internet: reflexões sobre a internet, negócios e a sociedade. Zahar.

Coni, V. J. \& Dantas, M. C. (2017). Constitucionalismo digital e a liberdade de reunião virtual: Protesto de emancipação da sociedade da informação. 4465f. Artigo. Revista de Direito, Governança e Novas Tecnologias.

Dallari, D. de A. (1984). O que é participação política. Brasiliense.

Dantas, M. C. (2009). Constitucionalismo dirigente e pós-modernidade. Saraiva, 2009.

Dantas, M. C. (2011). Direito fundamental ao máximo existencial. V.2. 2011. 436f. Tese (Doutorado) - Faculdade de Direito. Universidade Federal da Bahia/ UFBA, Salvador

Ferreira Filho, M. G. (2001). A democracia no limiar do século XXI. Saraiva.

Freire, P. (1967). Educação como prática da liberdade. Paz e Terra, 1967.

Freire, P. (2000) Pedagogia da indignação: cartas pedagógicas e outros escritos. UNESP.

Freire, P. (2001). Política e educação, 23. (5a ed.), Cortez.

G1- GLOBO. Cresce o número de jovens entre 15 e 29 anos que não estudam nem trabalham. https://g1.globo.com/educacao/noticia/cresce-o-numero-dejovens-entre-15-e-29-anos-que-nao-estudam-nem-trabalham.ghtml?utm_source=facebook\&utm_medium=social\&utm_campaign=g1 .

Habermas, J. (1997) Direito e democracia: entre facticidade e validade. (4a ed.), Tempo Brasileiro.

IBGE-EDUCA, Conheça o Brasil - População: Educação. https://educa.ibge.gov.br/jovens/conheca-o-brasil/populacao/18317-educacao.html Kelsen, H. (2000). A democracia. (2a ed.), Martins Fontes.

Limberger, T. (2016) Cibertransparência, informação pública em rede: A virtualidade e suas repercussões na realidade. Porto Alegre: Livraria do advogado.

Marques, F. P. J. (2016). Ciberpolítica: Conceitos e experiências. Edufba.

ONU, Declaração universal dos direitos humanos. http://www.ohchr.org/EN/UDHR/Documents/UDHR_Translations/por.pdf.

Participa.BR, Colabore no passo a passo das consultas públicas e discussões de políticas públicas. http://www.participa.br/. 
Research, Society and Development, v. 10, n. 7, e35810716789, 2021

(CC BY 4.0) | ISSN 2525-3409 | DOI: http://dx.doi.org/10.33448/rsd-v10i7.16789

Rolnik, R. et al. (2013). Cidades Rebeldes: Passe livre e as manifestações que tomaram as ruas do Brasil. Bom tempo. Carta Maior.

Rosenfield, D. L. (2003). O que é democracia. (5a ed.), Editora Brasiliense.

Santaella, L. (2003) Culturas e artes do pós-humano: da cultura das mídias à cibercultura. (4a ed.), Paulus.

Sartori, G. (1994). A teoria da democracia revisitada: Volume I- O debate contemporâneo. Ática.

Schumpeter, J. (1961). Capitalismo, socialismo e democracia, Editora Fundo de Cultura.

The Economist, The Economist Intelligence Unit's Democracy Index. https://www.economist.com/graphic-detail/2018/01/31/democracy-continues-itsdisturbing-retreat.

Transparency International. Índice da percepção da corrupção 2020. https://static1.squarespace.com/static/5a86d82132601ecb510239c2/t/ 5a8dc5b89140b72fa5081773/1519240719239/IPC+2017++RELATO\%CC\%81RIO+GLOBAL.pdf.

Wikilegis. Novas medidas contra a corrupção. http://novasmedidas.transparenciainternacional.org.br/wikilegis. 